LA ÉTICA EN LA OBRA DE HERBERT MARCUSE

GONZÁLEZ MORENO JAIRO ANDRÉS

UNIVERSIDAD SANTO TOMAS

FACULTAD DE HUMANIDADES

MAESTRÍA EN FILOSOFÍA LATINOAMERICANA BOGOTÁ D.C

2015 


\section{LA ÉTICA EN LA OBRA DE HERBERT MARCUSE}

GONZÁLEZ MORENO JAIRO ANDRÉS

Asesor de trabajo

DAMIÁN PACHÓN SOTO

Trabajo de grado para optar por el título de

Magister en Filosofía Latinoamericana

UNIVERSIDAD SANTO TOMAS

FACULTAD DE HUMANIDADES

MAESTRÍA EN FILOSOFÍA LATINOAMERICANA

BOGOTÁ D.C

2015 


\section{AGRADECIMIENTOS}

Agradezco fundamentalmente a mi familia por su apoyo constante y fuerza espiritual, a aquellas amistades que con su conocimiento aportaron directa o indirectamente a la consecución de este trabajo e inexorablemente al profesor Damián Pachón Soto por su paciencia y sapiencia en el enrutamiento de ésta tesis. 


\section{DEDICATORIA}

Este trabajo va dedicado a todos aquellos cuya humanidad les permite creer en la posibilidad de un mundo más ético, a familiares y amigos que motivaron en mí el pensar en la posibilidad de un hombre libre y dichoso 


\section{ÍNDICE}

INTRODUCCIÓN

\section{CAPÍTULO I}

GÉNESIS Y ACTUALIDAD DE LA SOCIEDAD INDUSTRIAL AVANZADA 6

I. Introducción $\quad 7$

II. Occidente entre finales del siglo XVIII y la primera mitad del siglo XX 9

a) El nacimiento del capitalismo y la historia como categoría filosófica $\quad 16$

b) La gran Guerra, Periodo entre Guerras y la II guerra Mundial 19

III. La Segunda Mitad del Siglo XX 25

a) La Sociedad Industrial Avanzada 30

\section{CAPÍTULO II}

LA NEGATIVIDAD EN HERBERT MARCUSE 32

I. Introducción 33

II. La relación entre el Psicoanálisis y el Marxismo en Marcuse 36

a) Marx y el materialismo histórico 37

b) Freud: entre el Principio de Realidad y el Principio de Placer 44

\section{CAPÍTULO III}

LA ÉTICA EN HERBERT MARCUSE 53

I. Introducción 54

II. Hacia un Concepto de Ética 57

III. La ética en Herbert Marcuse 60

a) La ética Individual 63

b) La ética Social 66

c) La ética Ambiental 73 


\section{CAPÍTULO IV}

LA ÉTICA DE HERBERT MARCUSE EN COLOMBIA 76

$\begin{array}{lll}\text { I. Introducción } & 77\end{array}$

II. La ética de Herbert Marcuse en Colombia 78

III. La Sociedad Industrial Avanzada en Colombia 80

IV. El Trabajo en la Sociedad Industrial Avanzada en Colombia 91

$\begin{array}{ll}\text { CONCLUSIÓN } & 94\end{array}$

$\begin{array}{ll}\text { BIBLIOGRAFÍA } & 98\end{array}$ 


\section{INTRODUCCIÓN}




\section{INTRODUCCIÓN}

Una de las preguntas fundamentales de la filosofía gira en torno a la ética; hablar de ética no es cosa menor, razón por la cual cada sociedad ha intentado dar respuesta a ella desde su sentir histórico, es decir que la ética acuña respuestas prácticas exclusivamente desde la reflexión crítica de lo que está viviendo en su más estricta actualidad, por lo tanto, lo que acá nos proponemos es aproximarnos al análisis de lo que somos éticamente como sociedad, entendiendo que las sociedades actuales han sido permeadas por la industrialización el tipo de Sociedad a que haremos referencia puntualmente es a la Sociedad Industrial Avanzada, esto inmediatamente nos condiciona a un tiempo especifico que podemos enmarcar a la segunda mitad del siglo XX hasta nuestros días y necesariamente nos dirige a un pensador que logró caracterizar, de la mejor manera desde nuestro parecer, ésta tipología de sociedad como lo fue Herbert Marcuse.

Entonces la investigación que acá presentamos tiene como problema central La ética en la obra de Herbert Marcuse. Si bien las referencias puntuales que realizar Marcuse a la ética a lo largo de sus obras son escasas, todo su corpus filosófico es implícitamente una propuesta de libertad y dicha por parte de los individuos, son denuncias pertinentes y sugerencias viables al cambio dentro de las Sociedades Industriales Avanzadas, razón que justifica la primacía por la pregunta ética en el contexto actual.

Necesariamente el lector se preguntará el por qué de Marcuse y no otro pensador dentro de la ética, y la respuesta la encontramos en la misma figura de Marcuse; no es una casualidad que en su obra sea latente la influencia directa de personajes tan determinantes en el pensamiento occidental del siglo XX como Husserl y Heidegger quienes fueron sus maestros, pero con igual impacto llegaron a él las obras de Hegel, Marx y Freud, esto de por sí ya establece la pertinencia de su cuidadosa lectura y decimos cuidadosa en la medida que la riqueza de pensadores que lo determinaron dieron fruto a un complejo pensamiento con tal originalidad que establece límites y alcances entre ellos y él, aportando categorías necesarias para entendernos como parte de una actualidad social que en ultimas cohesiona todo lo que llamamos occidente. 
No es una estéril lectura que hace Marcuse de importantes pensadores, como si fuese un simple eco de ellos, lo que acá Marcuse nos deja como legado fundamental es el diálogo que realiza desde su pensamiento original permeado por dichos pensadores y la Sociedad Industrial avanzada, es importante recordar que su vida comienza en las postrimerías del siglo XIX en Alemania (1898), esto nos da una justificación más del por qué estudiarlo, pues su vida se va a determinar directamente por hechos históricos como la Primera Guerra Mundial, el ascenso de los totalitarismos, la Segunda Guerra Mundial y posteriormente su vida en los Estados Unidos de América, por la Sociedad Opulenta que el mismo se dedicó a estudiar y cuestionar hasta su último día de vida el 29 de julio de 1979, en la plenitud de la Guerra Fría.

Su vinculación a la denominada Escuela de Fráncfort dirigida por Max Horkheimer y el planteamiento de la teoría crítica que de ella nace permitieron colocar a Marcuse junto a fundamentales pensadores del siglo XX como Adorno, Walter Benjamín, Erich Fromm, Habermas, en distancias significativas de la especulación filosófica, para centrarse en la discusión crítica directa de la sociedad desde su más inmediata realidad.

A lo largo de este trabajo hay una aproximación al pensamiento de Marcuse desde el filtro de la ética, pero para poder llegar a este objetivo fundamental nos vimos obligados a andarnos dialécticamente haciendo justa coherencia a la metodología de Marcuse, en este sentido, el llegar al hallazgo de la ética en la obra de Marcuse requirió partir del juego dialéctico que la misma historia nos obliga a seguir, empero, para llegar al sentido del problema acá planteado nos valimos metodológicamente de la hermenéutica, por lo tanto, se realizó una minuciosa lectura de las obras fundamentales de Marcuse preseleccionado jerárquicamente las ideas que de allí brotaban de acuerdo a su proximidad a la ética, y para hacer más objetiva la investigación decidimos escalonar la pregunta por la ética de la obra de Marcuse de tal forma que el trabajo acá desarrollado se divide en cuatro capítulos que paulatinamente nos fueron abriendo puertas que nos ubicaran concretamente en la propuesta ética de Marcuse. 
El primer capítulo es un acercamiento a la Génesis de la sociedad Industrial Avanzada, si bien Marcuse estructura gran parte de su obra a partir de este tipo de sociedad, mal haríamos en partir ciegamente de una Sociedad desconociendo su verdad originaria, en este orden de ideas, analizamos la Sociedad Industrial desde finales del siglo XVIII hasta la actualidad de dicha sociedad, para ello tuvimos que inmiscuirnos en la historia misma, analizando procesos políticos y económicos que caracterizan y constituyen al hombre contemporáneo; entre ellos podemos mencionar la primera parte de la Revolución Industrial que de la mano de la mano de la Revolución Francesa establecieron las bases de un nuevo hombre y una nueva sociedad, el desarrollo del liberalismo comandado por una naciente burguesía, el desarrollo del capitalismo, la primera guerra Mundial, la Gran depresión, el Ascenso de los Totalitarismos, la Segunda Guerra Mundial, el Mundo en la segunda mitad del siglo XX para a manera de conclusión caracterizar someramente la Sociedad Industrial Avanzada.

Una vez establecida conceptualmente la Sociedad Industrial Avanzada el ascenso que damos hacia la ética nos obliga a esclarecer la Negatividad en Herbert Marcuse, al ser el pensamiento de Marcuse notoriamente dialéctico y como esencia del devenir histórico esta la negatividad. La Sociedad Industrial Avanzada genera contradicciones fundamentales para el avance a nuevas formas sociales, inexorablemente para entender la Negatividad en Herbert Marcuse en nuestro segundo capítulo analizamos las tensiones que nacen producto de la represión excedente sobre el hombre por ello Marcuse logra conectar el Psicoanálisis y el marxismo como alternativas de liberación y superación de dichas tensiones pues como lo vio Zuleta por su parte de igual forma lo hizo Marcuse:

En cambio, quienes consagran la separación de individuo y sociedad, llegan a tratar la "sociedad" como un fetiche y convierten todos los conflictos personales en un problema de adaptación a las instituciones, normas y valores vigentes, sin ver que toda desintegración concentra y expresa a su manera la estructura de la sociedad en que se produce: cada hombre es una forma particular de vivir la totalidad y conocerlo es conocer la sociedad que él es a su manera. (Zuleta, 1985, pág. 207) 
Dichas tensiones las encontramos de manera más clara en las dos principales obras de Herbert Marcuse: Eros y Civilización y el Hombre unidimensional, sin embargo, nos hemos valido de ensayos secundarios que nos ayudaron a establecer dichas tensiones dialécticas que de la mano de Marx y Freud se nos hacen más claras.

Al tener ya establecidas las tensiones que habitan en la Sociedad Industrial Avanzada, en nuestro tercer capítulo entramos de lleno en La Ética en Herbert Marcuse, para ello nos vimos obligados a establecer un concepto provisional de ética que nos sirviera de referente para determinar la ética en la obra de Marcuse, asimismo, instauramos tres vertientes necesarias de estudio a la misma ética y que producto de la lectura y re-lectura de Marcuse establecimos como la ética individual, la ética social y la ética ambiental. Tres categorías que se encuentran interconectadas en el marco de la Sociedad Industrial Avanzada. En este capítulo logramos mostrar la pertinencia de la pregunta ética en la obra de Marcuse como herramienta crítica de análisis de las realidades contemporáneas.

Sin embargo, si bien la Sociedad Industrial Avanzada posee características generales que la hacen claramente diferenciable de sociedades pasadas, esta sociedad industrial avanzada tiene manifestaciones particulares en los contextos que se concretan. En el último capítulo nos es inevitable trasportar el concepto de ética de Herbert Marcuse a la realidad colombiana, no con la intención de estandarizar manuales como históricamente se ha hecho, sino como herramienta de humanización, puesto que los problemas de exclusión económica y condicionamiento no nos son ajenos, por el contrario, nuestras realidades están sujetas a las dinámicas políticas, económicas y culturales del dominio, es en este sentido que el trabajo tendrá una pretensión de llevar esta reflexión al contextos que nos compete, sin olvidar que a pesar que nuestras dificultades sociales se particularizan en la región la globalización ha hecho desgracias semejantes en otras regiones; la particularización de nuestra región obedece al inexorable desarrollo de los procesos históricos, donde a pesar de ser afro-descendientes, indígenas, mestizos, etc., somos mirados desde arriba como piezas del sistema. Además, de dictaminar los aportes de una ética de Marcuse a las sociedades colombianas analizamos la recepción de su pensamiento en el país. 
Nuestro último apartado lo dedicamos a unas breves conclusiones que más que cerrar arbitrariamente lo que hacemos es generar un balance de los logros alcanzados y dejar sugestivamente el panorama abierto a profundizaciones y nuevos horizontes. 


\section{CAPÍTULO I}

\section{GÉNESIS Y ACTUALIDAD DE LA SOCIEDAD INDUSTRIAL AVANZADA}




\section{Introducción}

“...la filosofía de la historia no es otra cosa que la consideración presente de la Historia; y nosotros no podemos dejar de pensar en ningún momento. El hombre es un ser pensante; en esto se distingue del animal. En todo lo humano, sensación, saber, conocimiento, apetito, voluntad - por cuanto es humano y no animal - hay un pensamiento; por consiguiente, también lo hay en toda ocupación con la Historia” (Hegel, 1963, pág. 787)

Quisiera partir de la idea de Historia propuesta por Hegel en las Lecciones de la Filosofía de la Historia Universal; sólo podemos hablar de Historia desde la mirada retrospectiva del presente en cuanto que esencialmente desde allí podemos razonar lo acontecido, es decir, lo que compete a la Historia. Al ser la Historia condición humana, ya que en lo humano está el pensar, su movilidad perpetua requiere de la interpretación humana, que siempre busca la explicación para una auto-comprensión. Si bien no es competencia de la filosofía establecer predicciones, ella si puede pensar en torno a lo acontecido, en este sentido, la Historia se convierte en sustrato de la filosofía y más aun a partir de la universalidad que es la misma Historia para la humanidad y por tanto para la filosofía. La universalidad de la historia se comprende en cuanto la imposibilidad que tiene cada ser humano de vivir sin tiempo ni espacio, es decir: sin Historia.

En este orden de ideas nos direccionaremos a un tiempo y un espacio concreto para determinar lo que la Historia ha tejido hasta hoy, y esto se hará para vislumbrar el punto de partida de la sociedad y los hombres institucionalizados en el aquí y en el ahora.

El proceso histórico de la construcción del hombre contemporáneo da inicio a finales del siglo XVIII y se evidencia hasta nuestros días, sin embargo, no podríamos afirmar de manera arbitraria que desde este punto de partida hasta nuestros días exista una armónica continuidad del proyecto de progreso que ha hecho eco a lo largo de los dos últimos siglos; 
con el propósito de hacer compresible la constitución del hombre y la sociedad contemporánea dividiremos en dos momentos concretos este devenir histórico para mostrar. Una primera instancia más o menos homogénea la podemos ubicar entre lo que fueron las últimas décadas del siglo XVIII hasta la primera mitad del siglo XX y una segunda desde 1945, es decir, terminada la segunda guerra mundial, hasta nuestros días.

Si bien hay una continuidad de la revolución industrial y de la idea del liberalismo, no podríamos afirmar que la misma revolución industrial de finales del siglo XVIII y los mismos ideales románticos del liberalismo hijo de la Revolución Francesa son los mismos avances de la industria y el neoliberalismo actual; pues de ser así afirmaríamos un final de la historia a partir de la caída de la modernidad.

Ya hemos hecho referencia a un tiempo concreto dentro del cual nos vamos a limitar, ahora requerimos de un espacio, y este espacio será lo que denominamos occidente.Pese a que dentro de éste espacio una parte de él se niega a su occidentalización asumiremos como occidente lo que ha sido permeado por el origen de la sociedad contemporánea; el propósito no es desarrollar un debate, que de por sí es válido y necesario, entre occidentales y occidentalizados, el propósito es ir al análisis de lo que se ha estructurado genéricamente en torno a un proyecto social que surge en las postrimerías del siglo XVIII y es originariamente occidental: La edad contemporánea.

En este orden de ideas es importante aclarar que la finalidad de este documento no es realizar a manera sistémica y cronológica la presentación de datos históricos, es decir, este texto no intenta abarcar los campos de competencia del historiador, sino desarrollar la reflexión filosófico-antropológica que de sustento al análisis crítico de una nueva ética a partir de la realidad histórica. 


\section{Occidente entre finales del siglo XVIII hasta la primera mitad del siglo XX}

El ocaso del siglo XVIII es el inicio del hombre contemporáneo, donde: "Todas las filosofías de la ilustración francesa y sus sucesoras revolucionarias entendieron la razón como fuerza histórica objetiva, la cual, una vez liberada de las cadenas del despotismo, hará de la tierra un lugar de progreso y felicidad" (Marcuse, 1994, pág. 13). Los ideales del liberalismo propondrían un nuevo hombre para un nuevo mundo, este quiebre histórico sentaría las bases en los ideales de la ilustración; el liberalismo dotaría a la burguesía de armas éticas para la consecución de la felicidad, ahora la felicidad tendría como aliada la razón libertaria y la mirada garante de un estado liberal. En el inicio del Estado liberal está el origen del hombre y la sociedad de hoy, al menos en términos político-ideológicos. "El hombre había pasado ya el largo periodo de inmadurez durante el cual fue víctima de abrumadoras fuerzas naturales y sociales, y se había convertido en el sujeto autónomo de su propio desarrollo" (Marcuse, 1994, pág. 10), en este sentido,emergía el momento coyuntural de superar la minoría de edad y virar estrictamente hacia la razón, pues en ella está el sustento de un nuevo hombre, la razón desataría un periodo revolucionario.

Este periodo revolucionario tenemos que centrarlo en dos revoluciones, por un lado la Revolución Industrial y por el otro la Revolución Francesa. "Si la economía del mundo del siglo XIX se formó principalmente bajo la influencia de la Revolución industrial inglesa, su política e ideología se formaron principal bajo la influencia de la Revolución Francesa" (Hobsbawm, 2012, pág. 58).

Indiscutiblemente tendremos que hacer referencia a dos momentos concretos que determinaran una nueva concepción del mundo y forjan las sociedades contemporáneas, estos dos momentos determinaron cambios políticos y económicos sustanciales, un primer momento lo ubicamos en la Revolución Industrial inglesa de finales del siglo XVIII y el otro en la Revolución Francesa de 1789, el primero potenciaría nuevas formas económicas y el segundo la evolución política, y conjuntamente constituirán el inicio de las sociedades contemporáneas. 
Como ya habíamos aclarado no es la intención entrar en un historicismo, sino ir a las bases que sustentan el origen de la sociedad industrial avanzada, y en esta búsqueda originaria la Revolución Industrial es el pilar económico de éste origen, en palabras de Hobsbawm:

¿Qué significa la frase «estalló la Revolución industrial»? significa que un día entre 1780 y 1790, y por primera vez en la historia humana, se liberó de sus cadenas al poder productivo de las sociedades humanas, que desde entonces se hicieron capaces de una constante, rápida y hasta el presente ilimitada multiplicación de hombres, bienes y servicios (Hobsbawm, 2012, pág. 36).

Este cambio cuantitativo y cualitativo rompió las barreras impuestas por el absolutismo en el mercado, si bien Europa desde siglos anteriores había apetecido de la magna creatividad e innovación Asiática, en el crepúsculo del siglo XVIII y principios del siglo XIX la importación de mercancías por países europeos ya no se desarrollaba en bloques regionales, sino que su actividad recaía en la individualidad comercial de algunos hombres, que paulatinamente fueron acumulando grandes riquezas.

Y tanto Gran Bretaña como el mundo sabían que la revolución industrial, iniciada en aquellas islas por y a través de los comerciantes y empresarios cuya única ley era comprar en el mercado más barato y vender sin restricción en el más caro, estaba transformando el mundo. Nadie podía detenerla en este camino. Los dioses y los reyes del pasado estaban inermes ante los hombres de negocios y las maquinas del presente (Hobsbawm, 2012, pág. 57).

En esta búsqueda de eficiencia, la razón le daba la justificación al mundo moderno: sólo a través de las habilidades cognitivas del hombre las sociedades podrían prosperar; éste sería un gran espaldarazo al positivismo, había que evidenciar el progreso y se estaba logrando. El abandono a la metafísica debido a su incompetencia a la hora de dar prueba de sus verdades, daría paso a un nuevo hombre, ahora la labor se direccionaba a justificar legalmente la racionalidad libre del individuo. Entonces, el obstáculo se vislumbraba en la estructura del Estado absolutista, su obsolescencia se argumentaba en lo poco pragmático que resultaba a la hora de dotar al individuo de sus inexorables libertades económicas y políticas, en torno a ello Montesquieu nos dirá: 
No hace falta mucha probidad para que un gobierno monárquico o un gobierno despótico se mantengan o se sostengan. La naturaleza de las leyes en el uno, el brazo del príncipe siempre levantado, en el otro, regulan o contienen todo. Pero en un Estado popular hace falta otro resorte que es la virtud (Montesquieu, 1963, pág. 546).

Pues es más virtuoso el gobierno que es capaz de gobernar desde y para el pueblo, que la escaza virtud de un gobernante que se ubica sobre las leyes.

Porque es claro que en una monarquía, donde el que hace ejecutar las leyes se considera por encima de las leyes, se necesita menos virtud que en un gobierno popular, donde el que hace ejecutar las leyes, siente que se halla sometido a sí mismo, y que soporta el peso (Montesquieu, 1963, pág. 546).

Para que toda ideología político - económica prospere en la praxis, es indiscutible que se debe valer de los aparatos del Estado para concretar sus objetivos, en este orden de ideas el fin del absolutismo significaría una reforma desde el mismo Estado, dando paso al Estado Liberal que se edificó a partir de la declaración de los Derechos del Hombre y del Ciudadano de 1789, sin embargo, como ya habíamos dicho es imposible disociar lo económico de lo político en este momento coyuntural, es más, si en aquel principio era difícil romper con estos nexos, a través de los años esta fusión se fue dando cada vez más dependiente al punto que hoy no se puede pensar lo uno sin lo otro, como no podemos pensar el origen de la sociedad contemporánea sin la Revolución Industrial ni la Revolución Francesa.

La libertad sería la bandera de este momento histórico; libertad política y libertad económica ahora se matizarían dentro del derecho natural, es decir, lo propio a cada individuo que desde su nacimiento le es innato, sin embargo, ¿de qué libertad los hombres ilustrados hablarían si la mayor parte del proceso histórico de la humanidad la libertad ha sido el privilegio de unos pocos ante la mayoría? pues es una minoría quien conceptualizó la libertad hacia la cual debería dirigirse Europa y en consecuencia occidente. Voltaire nos dirá en este aspecto: "Se ha acostumbrado uno también a no pronunciar la palabra libertad 
sin recordar todas las dificultades que la acompañan, que al presente casi no se entiende uno cuando se pregunta si el hombre es libre" (Voltaire, 1963, pág. 529). Quizás el presente al cual hacer referencia Voltaire sea un presente que aun vivimos, hablamos de libertad inconscientemente, pero hasta qué punto la libertad cae del mundo ideal a un mundo histórico, es decir, en qué medida la libertad se puede convertir en una praxis constante y evidente, ya Locke como teórico del Estado liberal nos había conceptualizado la idea de la libertad, diciéndonos:

Para entender el poder político correctamente, y para deducirlo de lo que fue su origen, hemos de considerar cuál es el estado en que los hombres se hallan por naturaleza. Y es éste un estado de perfecta libertad para que cada uno ordene sus acciones y disponga de posesiones y personas como juzgue oportuno, dentro de los límites de la ley de la naturaleza, sin pedir permiso ni depender de la voluntad de ningún otro hombre (Locke, 2010, pág. 10)

Esta vía abierta a la libertad sería un gran triunfo de la humanidad y principalmente para el mundo occidental que desde la Revolución Francesa de 1789 sostendría la bandera de la libertad, la igualdad y la fraternidad en el asta de los derechos del hombre y del ciudadano; ya no se condicionarían los hombres a los designios de un monarca absoluto pues todo estaría ahora regulado por un contrato social dentro del cual se pactan los limites, entonces la meta planteada por Rousseau era:

«Hallar una forma de asociación que defienda y proteja de toda la fuerza común la persona y los bienes de cada asociado, y por la que cada uno, uniéndose a todos, no obedezca, sin embargo, más que a sí mismo, y permanezca tan libre como hasta entonces». Tal es el problema fundamental cuya solución da el Contrato social (Rousseau, 1963, pág. 565).

En otras palabras el Contrato social, sería el ascenso constituyente del Estado liberal cuya panacea alejaría los fantasmas del dominio y la esclavitud, era el momento de romper con las cadenas de la minoría de edad y ser dueños absolutos de la razón propia. Aunque de antemano tendríamos que preguntarnos qué tan razonable puede ser el hombre que por sí mismo es incapaz de vivir éticamente y para asegurar su libertad debe cohesionar al mismo hombre a través de las leyes, pues la realidad es que las leyes son inversamente 
proporcionales a la ética. "Si la ausencia de represión es el arquetipo de la libertad, la civilización es entonces la lucha contra esta libertad” (Marcuse, 1984, pág. 30).Siendo la civilización un cumulo de normas, leyes y principios axiológicos que favorecen los intereses político-económicos particularizados en muchos casos que desconocen los intereses éticos que cada individuo gestiona para la consecución de su felicidad.

El ideal de progreso que se sustentaba en el hombre libre occidental ubicaría a la burguesía en la cúspide del poder político y económico, si bien las leyes buscaban llegar a la generalidad de los hombres la realidad era otra, mientras se promulgaba la libertad a la propiedad privada y a la libre empresa, el campesino o el obrero asalariado sólo verían en éste derecho natural una concepción simbólico-idealista que en la práctica social no se vislumbraba la manera de hacerla realidad en tanto que las mismas dinámicas del nuevo Estado Liberal impedían el acceso equitativo al capital, en este sentido, el derecho a la propiedad sería un derecho ejercido por pocos.

En este orden de ideas son innegables los éxitos de la Revolución Industrial y la Revolución Francesa en la medida que rompieron las cadenas con que el príncipe controlaba al pueblo, y jurídicamente ante la ley seríamos iguales, empero, el devenir del Estado Liberal y el ascenso de un nuevo modelo económico basado en la acumulación de capital abrirían profundas brechas sociales. Paradójicamente la injustificada premisa del absolutismo "el fin justifica los medios" y ante la cual se desbordó el mundo ilustrado para que a través de un contrato social se regulara, retornaría sigilosamente en el Liberalismo, ahora el fin era la acumulación de riquezas representadas en capital y los medios eran todos, es decir, cualquier mecanismo que garantizara dicha acumulación pues en ella habitaba la nueva felicidad.

En este panorama histórico las voces difícilmente podrían ser cayadas.La efímera igualdad en lo que se había convertido el ideal de la Revolución Francesa detonaría profundas contradicciones frente al originario proyecto de la ilustración; dentro de esta coyuntura encontraremos el germen del socialismo y el anarquismo como alternativa política y económica. Si bien el socialismo y el anarquismo de la primera mitad del siglo XIX no 
gozaban del suficiente peso filosófico al estar apenas en desarrollo si contribuirían a llevar la mirada a un nuevo sentido, y dentro de estas voces nuevas encontramos la figura de Pierre Joseph Proudhon quien cuestionaría el orden social instaurado desde finales del siglo XVIII. Para Proudhon el problema radicaba en la propiedad:

Nos encontramos en este punto muy lejos del derecho de propiedad absoluto e inalienable. ¡Así están el pobre y el rico en constante situación de desconfianza y de guerra! Y ¿Por qué se hacen la guerra? Por la propiedad: ¡de suerte que la propiedad tiene por consecuencia necesaria la guerra a la propiedad! La libertad y la seguridad del rico no obstan a la libertad y a la seguridad del pobre; lejos de ello, puede fortalecerse recíprocamente: por el contrario, el derecho de propiedad del primero tiene que estar incesantemente definido contra el instinto de propiedad del segundo. ¡Qué contradicción! (Proudhon, 2001, pág. 57).

Si la libertad de tener propiedad era restringida, por pocos para muchos, era evidente el problema, y si además de ello la acumulación de capital se condicionaba a la sumisión del otro, las promesas de igualdad distaban mucho de lo esencialmente planteado en la declaración de los derechos del hombre, en este sentido la contradicción planteada por Proudhon en torno a la propiedad no nos resulta un problema ajeno ni siquiera a nuestros días. Dentro del problema de la propiedad era inevitable que allí mismo la tierra tuviese que ser vista desde otras perspectivas.

La gran capa helada de los tradicionales sistemas agrarios del mundo y las relaciones sociales rurales cubría el fértil suelo del progreso económico. A toda costa tenía que ser derretida para que aquel suelo pudiera ser arado por las fuerzas de la iniciativa privada buscadoras de mejor provecho" (Hobsbawm, 2012, pág. 146).

Y para ello la tierra tendría que entrar en las nuevas dinámicas, es decir, la tierra debería de ser parte activa del comercio, por tanto, la técnica razonable del progreso permearía el sector agrícola lo cual significaba una inserción en el mercado libre e industrial, y para ello se requería de hombres libres cuya fuerza de trabajo guiara el mundo agrícola al mundo libre e industrializado. 
En este contexto social la pregunta fundamental era cómo resolver las brechas sociales que se habían generado, como ya habíamos dicho el surgimiento del socialismo y del anarquismo darían posibles salidas, y una manera de hacerlo era apoderar al pobre, políticamente y reubicarlo históricamente, pues la misma historia se había encargado de excluirlo y degradarlo a un simple engranaje de todo un sistema, en este sentido, revelarse ante éste sistema no era más que una consecuencia de la presión ejercida sobre el pobre trabajador principalmente del trabajador industrial. "Nada más inevitable en la primera mitad del siglo XIX que la aparición de los movimientos obrero y socialista, así como el desasosiego revolucionario de las masas. La revolución de 1848 sería una consecuencia directa” (Hobsbawm, 2012, pág. 196).

En 1830 y 1848 Europa viviría dos nuevas revoluciones una primera impulsada netamente por la burguesía donde el pueblo en su labor obrera defendería los intereses de unos pocos, decepción ante la cual para 1848 la nueva revolución tendría como ingrediente fundamental las nuevas corrientes socialistas; por tal razón el pueblo trabajador tendría que organizarse y constituirse ideológicamente ante las nuevas dinámicas sociales que atentaban contra su libertad. Pero para el trabajador pobre era más que un instrumento de combate: era también una norma de la vida. "La burguesía liberal no le ofrecía nada; la historia le había sacado de la vida tradicional que los conservadores prometían inútilmente mantener o restaurar" (Hobsbawm, 2012, pág. 204).Si los derechos del hombre y del ciudadano de 1789 dieron las armas legales al individuo para que defendiera su libertad, la publicación del Manifiesto del Partido Comunista el 24 de Febrero de 1848, día de su primera publicación en Londres, daría las armas político-ideológicas al pueblo para asumir su historia. La virtud de la revolución de 1848 se justifica en su rápida expansión por el continente europeo, si bien se puede catalogar la revolución de 1848 de exitosa su impacto real no trascendería los posteriores años.

Asimismo se evidenciaba una contradicción que para el socialismo, ya no el utópico de Fourier, Saint Simón, Robert Owen, sino el ahora científico de Federico Engels y de Carlos Marx: La burguesía había sido capaz de convertir en su extremo negativo al proletariado, ambiente apropiado para la revolución, pues la historia en Marx es fundamentalmente 
dialéctica y para que se pueda avanzar, la contradicción debe ser indiscutible, en palabras de Marcuse: "La práctica social del hombre encierra tanto la negatividad como su superación. La negatividad de la sociedad capitalista reside en la alienación del trabajo; la negación de esta negatividad podría obtenerse con la abolición del trabajo alienado" (Marcuse, 1994, pág. 277). Y la ruptura de esta alienación se pretendía concretar para 1848, empero, los mecanismos de la burguesía lograron controlar el ascenso del proletariado que veía en la revolución el punto de quiebre histórico.

Si bien habíamos afirmado que la revolución de 1848 había sido exitosa durante este año, su fracaso sería la manifestación de los años venideros, pese a ello la pretendida abolición de los movimientos obreros no lograría darse y el socialismo continuaría, casi que de manera clandestina, dotando ideológicamente al proletariado.

\section{a) El nacimiento del Capitalismo y la historia como categoría filosófica}

Dentro de la historia todo se encuentra en un devenir perpetuo exceptuando la misma certeza de la historia, es decir que no puede haber un universal más completo que la misma historia, en ella todo fluye pero nada es ajeno a ella. A lo largo de la historia de la filosofía la pregunta por la verdad y la realidad ha entrado en la dicotomía, en muchos niveles ambigua, entre un universal fuera de la percepción sensible y otro que parta de ésta. Con la filosofía moderna dicha discusión permanecería alejándonos de la noción de historia; por contrarias que parecieran las miradas filosóficas del racionalismo y el empirismo, y por más que en el idealismo alemán se pretendiera dar síntesis a estas dos corrientes, hay una verdad común que las va identificar como punto de partida que es el yo: yo pienso, yo siento, yo categorizo el fenómeno, etc., pero en ultimas un nosotros cohesionado desde la historia no hace presencia, ante lo cual Marx nos diría:

...allí donde termina la especulación, en la vida real, comienza también la ciencia real y positiva, la exposición de la acción práctica, del proceso práctico de desarrollo de los hombres. Terminan allí las frases sobre la conciencia y pasa a ocupar su sitio el saber real" (Marx, La Ideología Alemana, 1968, pág. 27). 
Así será el desarrollo del ser humano en su nuevo mundo de despotismo racional, donde la tenencia de patrimonio conduce a la felicidad y la misma felicidad se pierde en el adiestramiento lógico.

Somos consecuencia de una historia vista desde afuera, desde el anhelo, el misticismo, desde el racionalismo e idealismo, y no desde quienes hacen la historia, es decir, el mismo hombre, pero no el hombre impuesto y estereotipado, sino aquel hombre que existe desde su sociedad y que generalmente tiende a padecer más su existencia que a disfrutarla, pues el mundo de los artefactos y de los vacuos placeres cerró sus puertas ante él.

En este orden de ideas, la segunda mitad del siglo XIX vería el nacimiento de la ardua contradicción entre el yo y el nosotros, es decir, entre el Capitalismo y el Socialismo. Si bien no hay sociedad sin utopía, pues ella alimenta los proyectos que ésta emprende trazando rutas que conducen a la felicidad, la fuerza centrípeta de la historia pondría como epicentro dos utopías de la felicidad, el hombre estaría entre la encrucijada de su extrema individualidad o virar a lo social, empero, la negatividad era evidente.

Las sistemáticas invasiones de la Europa industrializada en Asia y África reflejarían el colapso del mismo hombre contemporáneo, la sumisión de pueblos y culturas ante la economía capitalista de pocas naciones privilegiarían el poderío económico sobre la misma ética; el hombre se dirigía hacia una desmandada ambición justificada en el progreso que llega hasta nuestros días de manera desigual, dichas invasiones que perdurarían de manera directa hasta finalizar la Segunda Guerra Mundial; siempre que estuviese la necesidad industrial de adquirir a bajo costo materias primas sustentaban su esencialidad y más aún cuando eran consecuencia del saqueo y de la barbarie de los civilizados, es decir, la sinrazón de la razón se imponía impidiendo hasta después de la Segunda Guerra mundial la soberanía de muchos pueblos de África y del sur oriente asiático que sufrían de manera directa la presión del despotismo industrial de las naciones europeas.

La agresión del otro se impone como estrategia de sumisión. Se someten a pueblos a fenómenos de aculturación, se somete la naturaleza a una extrema explotación y se somete 
al hombre a su más alta enajenación a través del trabajo. Es allí donde hace mayor presión la estructura de las sociedades industriales, en la imposición de un trabajo ajeno a la naturalidad humana, en palabras de Marcuse:

Es claro que el trabajo debe preceder a la reducción del trabajo, y que la industrialización debe preceder al desarrollo de las necesidades y satisfacciones humanas. Pero así como toda libertad depende de la conquista de la necesidad ajena, también la realización de la libertad depende de las técnicas de esta conquista. La productividad más alta del trabajo puede utilizarse para la perpetuación del trabajo, la industrialización más efectiva puede servir para la restricción y manipulación de las necesidades (Marcuse, 1985, pág. 48)

Entonces el hombre entra en una constante lucha contra su misma humanidad donde el otro es enemigo mientras posea las apetencias que la sociedad industrial avanzada ha generado, es decir, la agresividad se convierte en un medio de subsistencia, el instinto no sublimado de la agresividad aflora en el imaginario de la sociedad opulenta, en este sentido, el organismo social dentro de su perversa normalidad funcional se vale del temor para el control consiente e inconsciente de los individuos, siendo el trabajo el cohesionador del imaginario que la sociedad opulenta impone, pues aquel individuo sin trabajo pierde sus posibilidades legitimas de ascender socialmente, en ultimas el trabajo es quien establece el status dentro de la jerarquización social; asimismo el temor a la pérdida del trabajo rompe con el anhelo de parecer lo que la sociedad ha deseado de manera explícita e implícita, por tanto la agresividad es constante. Asimismo actuó el imperialismo europeo de finales del siglo XIX; no sólo fue la construcción de una maquinaria económica sólidamente estructurada, sino de igual forma una maquinaria de control del inconsciente.

La avanzada del imperialismo en Asia y África consolidaría a Inglaterra como potencia mundial, situación que la pondría en la mira de más naciones, pues el hombre siempre desea para si lo que otro está deseando, y en la era de los deseos creados, lo fundamental se verá fundido con lo natural, es decir, se perdería la brecha entre la satisfacción de las necesidades vitales y la satisfacción de las necesidades generadas por el contexto, es allí donde la mercancía se constituye en factor determinante del quehacer del hombre, ya Marx nos había dado luces sobre el papel de la mercancía en las sociedades contemporáneas. 
La mercancía es primeramente un objeto del mundo exterior, una cosa que por sus propiedades sirve para satisfacer, de alguna manera, las necesidades humanas. Nada importa cuál sea la naturaleza de esas necesidades: es igual que sean del estómago o de la fantasía" (Marx, 1950-53, pág. 86).

Sin embargo, el papel de la mercancía en la era de la industrialización fomento la búsqueda de reducción de costos para un máximo de ganancia, allí se encontraban naciones enteras que por imposición se convirtieron en proveedores de materias primas para que imperios ampliaran sus arcas de capital, empero, la rivalidad entre las naciones europeas por la tenencia del capital detonaría La Gran Guerra.

\section{b) La Gran Guerra, Periodo Entre Guerras y II Guerra Mundial}

Con facilidad podríamos hacer un seguimiento netamente histórico de la Gran Guerra haciendo revisión sistemática de causas, desarrollo y consecuencias, y como resultado probablemente obtendríamos lo que otras revisiones sistemáticas han logrado. En este orden de ideas viraremos al mismo hombre, a su más profundo inconsciente y a su propio tiempo.

En materia económica existía una claridad metodológica y razonable para la consecución del capital que venía impulsada por la industrialización, la continua estructuración la individualización requería de la sumisión directa o indirecta de la consciencia occidental, la misma enajenación del trabajador en la maquina contribuiría al control real y simbólico de sus vidas,

Al manipular la máquina el hombre aprende que la obediencia a las instrucciones es la única manera de obtener los resultados deseados. Arreglárselas bien equivale a estar ajustado al aparato. No hay campo para la autonomía. La racionalidad individualista se ha convertido en sumisión eficiente al continuo de medios y fines dado con anterioridad (Marcuse, 2001, pág. 60). 
Una vez controlada la consciencia del hombre, las estructuras violentas que históricamente el hombre ha desarrollado impulsarían sus fines a la supremacía dentro del Capitalismo; a los proyectos individuales de control se anexarían las consciencias subordinadas, que desde el nacionalismo veían un sentido de lucha. La Inglaterra de la primera década del siglo XX era el rival a vencer, su poderío colonial y control del atlántico la ponía en la mira de naciones cuyas intensiones eran abarcar lo conseguido por la industria británica; en tiempos de navegación industrial como escenario fundamental de comercio quien controlara el Atlántico aseguraría la supremacía comercial dentro del mundo occidental.

Dentro de esta lucha por la tenencia se desarrollan dos momentos históricos ideológicamente contrarios: la participación oportuna de Estados Unidos de Norte América en la Primera Guerra Mundial y la Revolución Rusa que obligaría a este último país a dar un paso al costado de la Gran Guerra y centrarse en el conflicto interno.

El mundo contemporáneo estaría marcado por una seguidilla de sucesos cuya fuente fue la racionalidad que la modernidad impulso, pero que irónicamente nos condujo al extremo de la irracionalidad, sin embargo, dentro de esta lógica de un supuesto progreso hay dos momentos históricos que determinan la reivindicación del hombre y su ser social e histórico dentro del mundo, aunque la mirada superficial nos mostrará una realidad particularizada en Francia y Rusia son dos eventos históricos que al hombre actual constituyeron. Por un lado la Revolución Francesa de 1789 entregó al mundo occidental un sentido de la libertad individual en el marco de la Declaración de los Derechos del Hombre y del Ciudadano que la ilustración impulsó, y por el otro, en 1917 la Revolución Rusa fomento para occidente los derechos sociales; la primera desde el liberalismo y la segunda desde el socialismo.

La Rusia de 1917 sería la última en ver el Zarismo como forma de gobierno absoluto, los Romanov se convertirían en la dinastía que ostentaría el poder dentro de Rusia desde 1613 hasta el estallido de la Revolución, momento en el cual se evocaría la revolución francesa en su metodología, es decir, el destino de los Romanov sería el mismo que llevó la monarquía francesa de 1789; si bien la ejecución de estas familias reales manifestarían similitud entre estas dos grandes revoluciones del mundo contemporáneo es la única 
evidencia de cercanía, pues la Revolución Rusa fundamentaría su intencionalidad desde la teoría marxista, haciendo la salvedad de los aportes que realiza Lenin en su brillante interpretación del contexto, puesto que las condiciones de la Rusia de los primeros años del siglo XX tendría un proletariado en germinación, una clase campesina excluida y soldados mal remunerados, estas condiciones llevaron a Lenin de la mano de Trosky y desde el exilio a crear lo que se conoció como los Bolcheviques. Sin embargo no se presentaría con facilidad la revolución, pues la burguesía rusa pretendía repetir lo logrado en la Revolución Francesa, es decir, posesionar a la burguesía en el poder, estos, los Mencheviques, verían como las clases más bajas tendrían voz en la figura de Lenin.

Por su parte Estados Unidos de Norte América haría su ingreso a la Primera Guerra Mundial el año de 1917 a consecuencia del hundimiento por parte de los alemanes de la embarcación Lusitania el 7 de mayo de 1915. El mundo estaba inmerso en una extraña paradoja que se convertiría en la constante del siglo XX, por un lado el éxito Norte Americano abanderando el capitalismo radical, y por el otro, la unión soviética cuyo frente de lucha ideológico era el socialismo. Al finalizar la Gran Guerra, como se le conoció popularmente, dejó a los Estados Unidos de América en la cima del capitalismo, su ingreso tardío a la guerra mundial permitió el desgaste de demás naciones combatientes mientras ellos entraban alivianados a la contienda. Pero por el otro lado, es decir, la unión soviética, se constituiría en un imperio territorial, ninguna nación se acercaba a la fortaleza territorial de la nueva Rusia (URSS).

El hombre mostraría sus alcances en materia de progreso militar, siendo este el sustento violento que permitiría que el capitalismo se convirtiera en la maquinaria aplastante del siglo XX. La llegada de la aviación como método de guerra, las interminables líneas de trincheras, la guerra química, etc., comenzarían a cuestionar los alcances de dicho progreso, empero, ahora Estados Unidos estaría tan resuelto a hacer del capitalismo su política imperial que concretaría las herramientas de control que serían de gran novedad. 
Una vez terminada la Primera Guerra Mundial en 1918, se firma el Tratado de Versalles entre las naciones vencedoras el 28 de Junio de 1919, condenando a la reparación a Alemania y sus aliados, situación que detonaría una nueva guerra.

El desconcierto existencial que había generado el desarraigo por la vida desde finales del siglo XIX ubicaría al hombre en una nueva era, en la era de los deseos, este mundo de padecer, constituido y representado, requería encajar en el inconsciente los deseos, y para ello el triunfante capitalismo fomentaría deseos no naturales a la naturaleza humana. Ahora en el inconsciente habitaba el consumo como característica del hombre del siglo XX, la disminución del Estado en cuanto lo económico evidenciaba un espejismo de progreso, la teoría ultra liberal de Adam Smith y David Ricardo parecía ser un manual garante del avance económico, sin embargo, la sociedad adormecida por el imaginario inconsciente del triunfo capitalista hacía prever la ilusión del final de la historia, donde el avance llegaría a perpetuarse. Que realidad más ingenua se enfrentaba la sociedad norte americana, pues la vida crediticia de industrias e individuos colapsará ante la falta de solvencia económica, el sobre endeudamiento imposibilitaría el consumo que con anhelo había construido la nueva soberana del capitalismo, al bajo consumo inevitablemente llegaría la quiebra bursátil, situación que haría replantear esa utopía de mercado estable, continuo, próspero y autónomo dentro del Estado, convirtiéndose la depresión de 1929 en la primera gran crisis del capitalismo que vería una luz al final del camino en políticas económicas estatales más proteccionistas ejecutando medidas de inversión en lo público y patrocinando industrias que ya se habían declarado en banca rota, siendo la principal novedad la reclusión de obreros ya desempleados a las industrias bélicas de Estados Unidos de Norteamérica.

La Segunda Guerra Mundial sería episodio inexorable que la historia no podría liberarse y menos cuando los intereses de revancha bélica estaban tan presentes; la formación de totalitarismos europeos (fascismo, franquismo y nazismo) fue impulsada por líderes que desde el nacionalismo pretendían reivindicar su posición en el mundo.

Ya mucho antes de la guerra mundial había comenzado a celebrarse, la aparición de un nuevo tipo de hombre que encontró adeptos en casi todas las ciencias del espíritu, desde la 
economía política hasta la filosofía. En toda línea se inició el ataque contra la racionalización y tecnificación hipertrofiada de la vida, contra el "burgués" del siglo XIX con su pequeña felicidad y sus pequeños fines, contra el espíritu de almacenero y comerciante y contra la "anemia" corrosiva de la existencia. Frente a todo esto se oponía una nueva imagen del hombre, resultante de una mezcla de ingredientes tomados de la época vikinga, de la mística alemana, del Renacimiento y del militarismo prusiano: la imagen del hombre heroico, ligado a las fuerzas oscuras de las que emana su vida (Marcuse, 1967, pág. 16).

Como bien lo señala el mismo Marcuse hasta la filosofía daría su adhesión a los movimientos totalitarios europeos, tal es el caso del mismo Heidegger quien en el año de 1933 haría pública su cercanía con el Nazismo. El Dasein heideggeriano vería su máximo esplendor en la autenticidad de la raza aria, la agresividad física de sometimiento a pueblos enteros encontraría una justificación filosófica convirtiéndose el filósofo en persecutor de su maestro (Husserl), situación que llevaría al exilio a gran cantidad de prominentes pensadores.

El nacimiento de los totalitarismos pondría en gran fervor el nacionalismo inspirado en una superioridad auto-determinada que a partir de figuras casi mesiánicas como Mussolini, Franco y Hitler percibían la personificación de la revancha, superioridad e inclusive la figura del padre protector del que habían carecido.

Dentro de las dinámicas de la Segunda Guerra Mundial se evidenció la ausencia de combates que llegaran a una última instancia hombre a hombre, la ciencia y la razón se habían valido de sus más grandes esfuerzos para hacer de la carrera armamentista la garantía del poder, a tal punto que la muerte ya no llegaba a través de las manos del hombre sino de la misma máquina, liberando de toda carga ética a quien oprimía un botón para desatar la barbarie.

Ahora la sociedad desde su más histórica hipocresía se sitúa moralmente dentro de lo que ella misma ha decidido arbitrariamente como lo bueno o lo malo. Ya la moral judeocristiana que ponía el matar como lo pecaminoso se mantiene al margen de las dinámicas de agresividad de las sociedades contemporáneas; el asesino que se vale de la tecnología 
para exterminar a su enemigo es héroe de la patria, así su actuar obedezca a intereses que justifican la sociedad enferma. "el asesino permanece limpio, tanto física como mentalmente” (Marcuse, 1981, pág. 122) y sumándole a la apreciación de Marcuse también se sentía despojado de toda responsabilidad moral.

Básicamente, al igual que la Primera Guerra Mundial, la Segunda Guerra Mundial fue un pulso entre las naciones más poderosas del mundo, con la novedad que para esta contienda la técnica militar se había superado ampliamente respecto a su antecesora, momentos puntuales como la invasión de Polonia y la casi desaparición de Varsovia desde el 1 de septiembre de 1939 por parte de los Nazis al inicio de la guerra, las antinaturales alianzas desde lo político como se alcanzaba a percibir entre Estados Unidos y Rusia, los campos de concentración como Auschwitz, Treblinka, Dachau, Belżec, y Bergen-Belsen por citar unos pocos, el ataque de Pearl Harbor del 7 de diciembre de 1941 y el lanzamiento de las bombas atómicas sobre Hiroshima y Nagasaki del 6 y 9 de agostos de 1945 respectivamente, harían de estas particularidades el nacimiento de la urgencia por pensarnos y repensarnos como parte del mundo, pues los alcances de la racionalidad individualista y excluyente del hombre contemporáneo nos estaba llevando al exterminio.

Hasta acá hemos visto como desde finales del siglo XVIII hasta 1945 año de culminación de la Segunda Guerra Mundial el capitalismo como sistema económico, cuya raíces se entretejen en el liberalismo, ha mantenido de cierta forma algunos esquemas que podríamos denominar homogéneos sin pretender con esto afirmar ingenuamente que la historia se estabilizó, la homogeneidad de este periodo más o menos extenso que hemos establecido se caracteriza en ser una fase del capitalismo donde la acumulación de capital producto de la enajenación del hombre en el trabajo permitió el ascenso individual de algunos hombres a una economía industrial; en esta primera parte de la sociedad industrial las contradicciones eran claras: habían unos pocos poseedores de la propiedad y por ende de los sistemas de producción y una clase social pobre que sostenía sobre sus cuerpos las apetencias de la burguesía, estos pobres trabajadores no añoraban para sí ocupar el lugar de la burguesía, por el contrario su estrategia, que en muchos casos divagaba entre el socialismo y el 
anarquismo, se enfocaba a romper los grilletes que cohesionaban la libertad. En este sentido:

La transformación del estado liberal en el estado total - autoritario se realiza dentro del mismo orden social. Con respecto a esta unidad de bases económicas puede decirse que es el liberalismo mismo el que genera al estado total-autoritario como si éste fuera su realización final en un estadio avanzado del desarrollo (Marcuse, 1967, pág. 27).

\section{La segunda mitad del siglo XX}

Cuando miramos en retrospectiva al hombre y la sociedad que se ha formado en el marco de la sociedad industrial, debemos intentar comprender el origen que ha condicionado una realidad que determina la vida de un mundo que se padece; los intereses del hombre contemporáneo han cambiado radicalmente, a tal punto que las necesidades básicas que garanticen la vida son suplantadas por estereotipos vacuos que sólo obedecen a la satisfacción de un mercado; la justificación histórica del proyecto de hombre y sociedad que se ha construido por más de dos siglos empieza a flaquear, el derrumbe de sus

promesas de progreso, la insostenibilidad ambiental, el exacerbado individualismo, la constante angustia ante un devenir incierto, pero poco alentador, son las características de las sociedades contemporáneas, en este sentido es oportuno cuestionarnos la vigencia de un proyecto efímero que ha erosionado la sociedad hasta su estado más antinatural.

No podemos decir ingenuamente que el liberalismo de hoy obedece a unas homologaciones del liberalismo de finales del siglo XVIII, si bien es un origen, sus matices han optado por dinámicas que diferencian estos dos momentos, por tanto es imprescindible hacer claridad de los cambios que se han estructurado hasta la evolución de lo que es el hombre y la sociedad actual. Si bien en toda forma de liberalismo la primacía está en lo individual, las primeras formas de liberalismo condujeron al capitalismo industrial y comercial para dar paso a un capitalismo monopolista que es el que evidenciamos en nuestras sociedades, en este sentido el devenir del liberalismo es profundamente dialéctico, y su verdad absoluta sólo está en el aquí y el ahora, por tanto, entrará inexorablemente en una nueva 
contradicción que negará dialécticamente este presente, pero que a su vez estará compuesta indisociablemente por él.

Una vez terminada la Segunda Guerra Mundial el balance no era alentador, pues las aspiraciones de progreso continuo y generalizado eran evidentes en pocos sectores, la devastación de ciudades enteras producto de la Guerra pondrían un gran interrogante sobre la apología a la razón y al progreso que se había gestado desde la modernidad. Sí la sociedad industrial avanzada contaba con los recursos suficientes para romper las crisis históricas de segregación social la paradójica situación vislumbraba otra realidad.

Si bien como consecuencia directa del fin de la Segunda Guerra Mundial surgen estamentos supranacionales para el control, organización y castigo que propiciaran el fortalecimiento del statu quo, la ruptura entre los poseedores y desposeídos se potenciaría; si en la dialéctica hegeliana del amo y del esclavo, el esclavo ha preferido sacrificar su libertad a cambio de la vida, el esclavo de la sociedad industrial avanzada pretende materializar su libertad en el consumo, a tal punto que la apariencia resulta más útil que la libertad, como lo diría Ortega y Gasset haciendo referencia a la Masa:

Es todo aquel que no se valora a sí mismo - en bien o en mal - por razones especiales, sino que se siente «como todo el mundo», y, sin embargo, no se angustia, se siente a sabor al sentirse idéntico a los demás (Ortega y Gasset, 1988, pág. 49)

En este orden de ideas, una sociedad con los recursos suficientes para terminar con los problemas que han aquejado al mundo contemporáneo es una sociedad en crisis, pues dentro del mundo del artefacto, del consumo, de la abundancia, etc., el hombre podría salir del mismo caos al que su progreso lo condujo, Marcuse define a esta sociedad como «sociedad enferma»:

Podemos decir que una sociedad está enferma cuando sus instituciones y relaciones básicas, su estructura, son tales que no permiten la utilización de los recursos materiales e intelectuales disponibles para el óptimo desarrollo y satisfacción de las necesidades individuales (Marcuse, 1981, pág. 104). 
Asimismo, la normalidad del caos se presenta como lo natural y ajeno a los mismos hombres, el hombre se ubica como un ser extraño dentro del mundo cosificado, es decir, la afectación por el otro se dispersa en incomprensión de la realidad, pues la brecha entre la ficción y la realidad se ha acortado a tal instancia que no se logra diferenciar la una de la otra, en este sentido, la proliferación de los medios masivos de comunicación fomentaron una inhumana habituación al contexto, generándose una parsimonia cómplice ante el caos, por tanto:

La brutalización de lenguaje y de la imagen, la presentación del asesinato, el incendio, el envenenamiento y la tortura de quienes son víctimas de las matanzas neocoloniales, se realiza en un estilo natural, objetivo y a veces humorístico, que asocia esos horrores con las hazañas de la delincuencia juvenil, los campeonatos de futbol, los accidentes, los informes bursátiles y el hombre del tiempo (Marcuse, 1981, pág. 114)

La segunda mitad del siglo XX es producto de un cumulo de factores que hacen de la sociedad industrial avanzada un fenómeno determinante en la condición de humanidad a la cual nos vemos sujetos y conducidos; dentro de estos factores que proliferan y particularizan este periodo podemos identificar y puntualizar el surgimiento del mundo bipolar, el nacimiento de instituciones supranacionales, el desarrollo de la tecnología de los medios de comunicación y en consecuencia la consecución del hombre y la sociedad unidimensional.

Terminada la Segunda Guerra Mundial la tensión persistía, el bloque capitalista liderado por los Estados Unidos de Norte América se enfrentaba a la Unión Soviética, enfrentamiento que más allá de lo ideológico no llego a la confrontación militar directa, sin embargo, en esta encrucijada se encontraba un mundo angustiado ante la latente amenaza del estallido de un conflicto nuclear las alianzas resultaban más del orden de la simpatía ante cierta ideología y sumisión por otro lado que verdaderos pactos entre naciones salvo algunas excepciones, la denominada Guerra Fría conduciría a la división de naciones entre el capitalismo y el socialismo: Alemania Federal y Alemania Democrática; Vietnam del sur y Vietnam del Norte, Corea del sur y Corea del Norte, situación que llevaría a Estados 
Unidos a optar por la doctrina Truman para evitar el dominio del bloque socialista sobre otras naciones y en paralelo a esta misma doctrina se desarrollaba el plan Marshall que oficialmente se conocía el EuropeanRecoveryProgram o ERP que consistía en el apoyo económico que intentaba la reconstrucción de naciones europeas víctimas de la Segunda Guerra Mundial y que de cierta forma se encontraban en un riesgo de ser sometidas por el poderío del bloque socialista.

En pleno desarrollo de la Guerra Fría surgen instituciones supranacionales con evidentes intereses parcializados, desde lo político y económico el Fondo Monetario Internacional FMI y el Banco Mundial tejerían paulatinamente las redes de la globalización donde más allá de sus originarios propósitos de contribuir a la reconstrucción de las naciones afectadas por la Segunda Guerra Mundial se encaminaron a generar la adhesión de naciones del tercer mundo al capitalismo globalizado, situación que al día de hoy posee un balance poco favorable a las naciones en vía de industrialización pues los compromisos adquiridos con estas naciones erosionó las economías de las naciones en desarrollo, de igual forma surge la OTAN, siendo la evidente alianza militar entre naciones norteamericanas y algunos países europeos.

Era obvio que el gasto económico que desarrollaba para la guerra Estados Unidos frente a la Unión Soviética no era proporcional, por más de cuatro décadas de amenazas de enfrentamiento directo el gasto militar fue el factor determinante de la culminación de la Guerra Fría, pese a no concretarse el conflicto bélico las tensiones latentes exigían que las fuerzas militares de cada bando estuvieran en constante alerta, es decir, éste estar en pie de guerra significaba gasto en innovación, en preparación, en manutención, etc., de las fuerzas militares, no era lo mismo enfrentase a una posible guerra desde la individualidad o las débiles alianzas a desarrollarlo desde bloques compactos de defensa militar como lo fue la OTAN, en este orden de ideas finalizando la década de los ochentas el bloque soviético paulatinamente fue cediendo hasta concretarse el fin de la guerra con la caída del muro de Berlín. 
Como ya lo habíamos señalado el mundo se encontraba expectante ante un latente conflicto que en últimas no interesaba a gran parte de los hombres comunes, el hombre se encontraba perplejo ante un capitalismo que dividía a los hombres entre poseídos o desposeídos pero de igual forma ante un socialismo soviético que resultaba muy contrario a los postulados marxistas, es decir, que los principios morales que abanderaban no explicaban la realidad del hombre cotidiano, empero, al caer entre el 9 y 10 de noviembre de 1989 el muro de Berlín se derrumbaba una visión malograda del mismo socialismo, prácticamente el mundo se encontraba bajo los designios del capitalismo estadounidense, si bien la guerra simbólica o psicológica ya gozaba de naturalidad dentro de la guerra donde el cine, la música, la televisión, etc., internaban en el inconsciente un ganador y un "bueno" que derrotaría a un "malo", es decir, que el enemigo de todo occidente, como abiertamente se dijo era el socialismo, una vez derrotada la Unión Soviética el aparato mediático del capitalismo continuo ejerciendo la presión en el individuo a niveles impredecibles, jamás en la historia se habría pensado en sustituir las necesidades por necesidades superfluas que sólo representasen un estatus dentro de la sociedad, pero de igual forma la historia no nos habría hecho pensar que la técnica nos permitiera generar tal inmediatez en la comunicación ahora los mass media dictaminan gran parte de la conducta humana sin permitirnos tomarnos el tiempo de decidir, los hombres estamos ahora pensados y hay cierto regocijo en algunos individuos ante esta situación.

De manera somera hemos desarrollado un esbozo de la génesis y desarrollo de la sociedad industrial avanzada para situarnos en una actualidad relativamente homogénea para occidente, allí en esa idea muchas veces ambigua que llamamos occidente habitan hombres cuyas tensiones condicionan su felicidad, si bien la ética es la libertad del desarrollo del proyecto de vida que conduzca a la felicidad hoy en día el hombre ha reprimido su existencia al punto que la libertad está determinada por el statu quo del sistema imperante, en por ello que se nos hace indispensable aproximarnos a dicha tensión entre la libertad y la imposición de la sociedad industrial avanzada, es decir, la lucha entre eros y tanatos. 


\section{a) La Sociedad Industrial Avanzada}

Como hemos visto la Sociedad Industrial va teniendo una metamorfosis en el tiempo que desde sus inicios finalizando el siglo XVIII hasta nuestros días ha condicionado la vida del hombre occidental, empero, cuando afirmamos que ha tenido una metamorfosis implícitamente hacemos referencia a que no es la misma la Sociedad Industrial de sus albores a la Sociedad Industrial Avanzada a la cual hace referencia Marcuse, es más, podríamos igualmente afirmar que la Sociedad industrial Avanzada descrita en la obra de Marcuse tiene características que el tiempo de nuestro pensador no permitieron predecir.

Cuando hablamos de Sociedad Industrial Avanzada nos referimos a la máxima expresión posible de una sociedad fundamentada en el progreso tecnológico donde el confort y la satisfacción de necesidades creadas dentro de esta misma sociedad se convierten en la panacea de la felicidad pese a que cada individuo debe hacer sacrificios antes insospechados, pues ahora el hombre ha puesto su libertad en niveles inferiores a la esencia misma de la vida, sin embargo, para llegar a este punto no se logró desde la consiente aceptación del mundo dado, sino desde la más fuerte represión que invadió el aparato síquico de los hombres, no es que la represión acá imperante sea exclusiva de estas sociedades, en toda sociedad habitan estructuras represivas, la gran diferencia es que para el correcto funcionamiento de la civilización actual la represión se ha extralimitado para establecer una sociedad unidimensional, es decir, que esta represión excedente ha homogenizado el control desde la esferas públicas y privadas a las cuales se dirige el individuo.

La Sociedad Industrial Avanzada a pesar de su poderío de transformación positiva ha sometido al hombre en la más profunda represión, una sociedad con la técnica para cambiar el mundo de la manera más ética se ha conducido con por el camino de menor libertad y dicha para los hombres; en las sociedades actuales el trabajo continua siendo enajenado a sí el tiempo y fuerza invertidos sean inferiores a sociedades industriales pasadas, las necesidades vitales son remplazadas por la imposición de necesidades no vitales, la represión llega al hombre por medio del impacto de los medios masivos de comunicación, 
la guerra es la justificación del bienestar, la fuerza libidinal se invierte en el mismo sistema, el medio ambiente es obstáculo para el desarrollo industrial, y, en consecuencia, todas estas dinámicas propias de las Sociedades Industriales Avanzadas sacan a flote inconformes que desde distintos flancos demandan por justicia, sin embargo, estos brotes de inconformismo pretenden ser absorbidos por el mismo sistema, es por ello que la Sociedad Industrial Avanzada impide, con gran éxito en muchas instancias, el desarrollo de la propia negatividad que le es propia. 


\section{CAPÍTULO II}

\section{LA NEGATIVIDAD EN HERBERT MARCUSE}




\section{Introducción}

Una vez analizada someramente la génesis y actualidad de la Sociedad Industrial Avanzada nos encontramos ante la sociedad y el hombre unidimensional, es decir, en aquel espacio social de la actualidad principalmente occidental, donde esta sociedad, forjada por el hombre unidimensional, "crea relaciones libidinosas con las mercancías, en ella el fetichismo por la mercancía obnubila la conciencia de la población.” (Pachón Soto, 2008, pág. 19).

Pues si el hombre que mentamos dentro de una actualidad ha entrado en un estado de vacía comodidad que la coseidadle da, su pretensión no se direcciona a romper los grilletes que la sociedad industrial avanzada ha colocado en él, al contrario, la brecha entre opresores y oprimidos parece desvanecer a través del desarrollo de necesidades no vitales que se han impuesto y al satisfacerlas de manera parcial o total se cree acceder a un placer que en lo práctico carece de una reflexión desde el otro, desde sí mismo y desde su entorno, es decir, lo ético pasa a un plano inferior a lo propiamente útil, entendiendo lo útil como el producto tangible que la sociedad crea para la satisfacción de nuevas necesidades, y por ende dista mucho de la felicidad.

En Herbert Marcuse encontramos una fuerte crítica a las sociedades contemporáneas, pues en las sociedades actuales la universalización de las condiciones existenciales del mundo han logrado ese carácter absoluto que la filosofía siempre ha pretendido, en tanto que las relaciones entre burguesía y proletariado han cambiado fundamentalmente su proceder unificando los ideales y proyectos de vida de los miembros de la sociedad. "Así surge el modelo de pensamiento y conducta unidimensional en el que ideas, aspiraciones y objetivos, que trascienden por su contenido el universo establecido del discurso y la acción, son rechazados o reducidos a los términos de este universo" (Marcuse, 1985, pág. 42). En este sentido, uno de los rasgos más relevantes de las sociedades contemporáneas, en cuanto a proyecto de occidentalización compete, es la marcada pretensión de hacer una sociedad

totalizada; si bien las dinámicas socio-culturales, miradas desde su particularidad, gozan de características concretas y autónomas, dicha pretensión de totalidad de una u otra forma han 
permeado las estructuras socio-culturales de las regiones mundiales. "La evolución que ha conducido a esta situación está caracterizada por el hecho de que la propia razón se ha convertido de simple medio auxiliar del «tinglado» económico, en utensilio universal utilizado para el fortalecimiento de las demás herramientas” (Mansilla, 1970, pág. 56).

Naturalmente, lo innatural de la lógica del hombre contemporáneo entregó el devenir del mundo a manos de la razón, por más que ella manifestara su irracionalidad principalmente durante la primera mitad el siglo $\mathrm{XX}$, el mundo se universalizaría bajo las mismas condiciones, es decir, dentro de la sociedad unidimensional, lo cual significaría la perdida de la negatividad evidente en la historia contemporánea, pues el hombre unidimensional no pretende entrar en una profunda contradicción sino al contrario se desvanece entre sus semejantes y para lograrlo se mimetiza como su opuesto: la brecha entre amos y esclavos, entre burgueses y proletariados, se ha difuminado en la niebla mediática, tal como nos diría Platón "el que hace una apariencia, el imitador, sólo conoce la apariencia, pero no entiende nada del ser" (Platón, 1966, pág. 352), sin embargo, la necesidad de pertenecía a un todo genera el espejismo de pretender ser dentro de todo un aparato sublimador que es la cultura, por lo tanto el hombre unidimensional existe dentro de la apariencia y la imitación, rompiendo la negatividad evidente entre las clases sociales del siglo XIX.

Cuando nos aproximamos al pensamiento de Marcuse inexorablemente nos conducimos a la dialéctica;la dialéctica de Marcuse es de origen hegeliana y marxista, por lo tanto la lectura metodológica de la sociedad se establece dentro de la contradicción; si afirmamos que la sociedad contemporánea ha alcanzado sus máximos logros materiales e intelectuales, y asumimos que el mundo es dialéctico, las contradicciones que emanan de las dinámicas sociales carecen de negatividad, es decir, las formas antagónicas en la sociedad, sin dejar de existir, han debilitado su poder de negación, y esto se explica en que los intereses del proletariado han sido absorbidos por intereses de la burguesía. "La sociedad industrial avanzada consigue estancar las fuerzas revolucionarias mediante la promesa de una elevación del nivel de vida" (Palmier, 1969, pág. 177); pero ante estas promesas el juego dialéctico persiste, ahora hay que evidenciarlo y hacerlo accesible a la sociedad contemporánea. 
La crítica - dialéctica que propone H. Marcuse se fundamenta en la negatividad existente dentro de la sociedad contemporánea; como ya habíamos señalado la dialéctica hegeliana y marxista es el sustrato de la dialéctica en H. Marcuse, pero no con ello podemos afirmar que existe una homologación metodológica. “Tanto en Marx como Hegel, la dialéctica observa el hecho de que la negación inherente a la realidad constituye «el principio creador y motor»" (Marcuse, 1994, pág. 276), sin embargo, H. Marcuse va más allá de este momento dialéctico; si lo que importa en H. Marcuse es la interpretación crítico- dialéctica de la sociedad, sería un error conceptual pensar en una dialéctica estática y dogmatizada, es decir, la misma dialéctica como método ha entrado inevitablemente en negación, para entrar en un movimiento que sólo en el aquí y el ahora pude manifestar su verdad, en este orden de ideas, la dialéctica hegeliana (burguesa-idealista) verá su negación en la dialéctica marxista (histórico - social).

El proceso de Hegel era, pues, un proceso ontológico universal, en el que la historia se modelaba según el proceso metafísico del ser. Por el contrario, Marx desliga la dialéctica de esta base ontológica. En su obra, la negatividad de la realidad se convierte en una condición histórica que no puede ser hipostasiada como situación metafísica. Dicho de otro modo, se convierte en una condición social, asociada a una forma histórica particular de sociedad (Marcuse, 1994, pág. 307)

Ahora la tarea es someter la crítica social a un nuevo movimiento dialéctico donde se armonice con el mismo movimiento social, pues hoy las dinámicas sociales son ajenas a los procesos que vieron Hegel y Marx, inclusive a los percibidos por el mismo Marcuse. En últimas la dialéctica es una constante actualización de sí misma cuyo devenir es el de la misma historia.

La conexión dialéctica de tesis, antítesis y síntesis es solo la expresión general de una ley fundamental de la movilidad histórica de esa vida: la «superación» necesaria, fundada en el ser de la vida, de la realidad histórica en cada ocasión, en la que la vida se encuentra (tesis) y que necesariamente representa una ruina de sus posibilidades (negación), el avance hacia una realidad más elevada y más verdadera que suprime a la primera (antítesis). Y este acontecer 
superador simultáneamente «preserva»: recoge las posibilidades positivas realizadas en la fase histórica dada (síntesis); esta remitido en un sentido fundamental a lo dado, como la superación que preserva solo puede acontecer a partir de las posibilidades preexistentes en cada caso: a partir del saber sobre el ser devenido de tales posibilidades, su ruina y su futuro (Marcuse, 2011, pág. 131)

\section{La relación entre el Psicoanálisis y el marxismo en Marcuse}

En primera instancia entraríamos a aclarar la relación interna que habita en el pensamiento de Herbert Marcuse entre Freud y Marx. A simple vista resultaría opuesta la confrontación entre la liberación libidinal del individuo y materialismo histórico, pero es precisamente en esta aparente contradicción donde aparece el aporte novedoso del pensamiento de Marcuse. Sin embargo hay un punto de encuentro concreto que es el desarrollo dialéctico en cada uno de ellos, por una parte la contradicción entre burguesía y proletariado y por otro el principio de realidad frente al principio de placer.

Si bien es obvia la influencia de Marx y Freud en la obra de Herbert Marcuse y en el desarrollo del pensamiento de la Escuela de Frankfurt, mal haríamos en afirmar ingenuamente que Marcuse se convertiría en un apologético de estos autores; por el contrario, la obra de Marcuse evidencia un diálogo directo entre la teoría freudiana y la teoría marxista-hegeliana, por lo tanto esta fusión no es resultado de las observaciones que Freud y Marx realizaron de la realidad, sino son la consecuencia de la búsqueda de herramientas que encaminen a la superación de la tensión dentro de la Sociedad Industrial Avanzada, en este sentido, la teoría de Marx y de Freud al ser dialécticas y no estáticas deben optar por su movilidad, devenir que nos traerá hasta la pregunta por las sociedades actúales y allí Marcuse plantea los alcances y limitaciones del marxismo y freudismo ante la realidad actual, para entrar en el campo propositivo. 


\section{a) Marx y el materialismo histórico}

Quisiéramos partir nuestra exposición de los alcances y deficiencias del marxismo que emanan de la lectura de la obra de Marcuse dentro del contexto de las sociedades actuales a partir de la sentencia categórica que derrumba el ingenuo imaginario de pensar en marxismo como un catecismo que actúa más por fe que por devenir histórico, de ser así no habría sentido en leer conscientemente a Marx, sino que nos bastaría con rezar y predicar sus postulados, ahora bien, como en la esencia marxista parte del idealismo dialéctico hegeliano para situarse dentro del Materialismo dialéctico hacemos inmersión en dos pilares fundamentales: por un lado entendemos que el movimiento dialéctico exige negación de su misma realidad por ende se derrumba la ingenua y errónea lectura de la filosofía marxista donde se asume como manual; y por otro lado nos dirigimos al materialismo dialéctico cuya esencia no es otra que la materialización de la historia. Una vez realizada esta somera aclaración entendemos que en Marcuse hay una revisión de la filosofía hegeliana y marxista para entenderla desde su propia actualidad. Entonces ¿qué significa pensar dialécticamente?:

En términos socio-históricos significa que, por lo general, las crisis y colapsos no son accidentes ni perturbaciones externas, sino que manifiestan la verdadera naturaleza de la cosa y, por ende, proporcionan la base para entender la esencia del sistema social existente. Significa además que las potencialidades intrínsecas del hombre y de las cosas sólo pueden desarrollarse en la sociedad mediante la muerte del orden social en el que antes se originaron. Hegel dice que cuando algo se convierte en su opuesto, cuando se contradice a sí mismo, expresa su esencia. Cuando, como dice Marx, la idea y la práctica corriente de la justicia y la igualdad conducen a la injusticia y la desigualdad, cuando el libre intercambio de equivalentes produce, por una parte, la explotación, y por otra, la acumulación de la riqueza, dichas contradicciones pertenecen también a la esencia de las relaciones sociales existentes. La contradicción es el motor del progreso (Marcuse, 1994, pág. 149)

Una de las críticas más fuertes que realiza Marx en su obra es a la brecha existente entre la filosofía y su práctica, un ejemplo de ello es su ya famosa tesis undécima sobre Feuerbach; para Marx "los filósofos se han limitado a interpretar el mundo de distintos modos; de lo 
que se trata es de transformarlo" (Marx, 1968, pág. 668); y para llegar a esta transformación es necesario ir directamente a la sociedad, a su historia, es decir, a la realidad, siendo esta una de las dificultades del mismo idealismo alemán, al no haber sido capaces de pensarse en términos históricos, en este sentido y volviendo con Marx, el punto de partida no es vertical, sino horizontal, "al contrario de lo que ocurre en la filosofía alemana, que desciende del cielo sobre la tierra, aquí se asciende de la tierra al cielo" (Marx, 1968, pág. 26), por tanto hay que ir al proceso de la vida real del hombre, allí donde el individuo pierde su autonomía, donde es ser imaginado y representado, y donde la superestructura condiciona el desarrollo social.

Para Marx la historia, es un proceso dialéctico material, es decir, no ideal, como lo planteaba la filosofía idealista que lo antecedió.

Es decir, no se parte de lo que los hombres dicen, se representan o se imaginan, ni tampoco del hombre predicado, pensado, representado o imaginado, para llegar, arrancando de aquí al hombre de carne y hueso; se parte del hombre que realmente actúa y, arrancando de su proceso de vida real, se expone también el desarrollo de los reflejos ideológicos y de los ecos de este proceso de vida (Marx, 1968, pág. 26)

Es innegable la influencia del pensamiento de Marx en Marcuse, sin embargo, dicha influencia no se condiciona a una apología ciega del marxismo, sino un referente para la comprensión de la sociedad contemporánea. En este sentido, en palabras de Marcuse:

El marxismo no es un «sistema ideológico cerrado». Su objetividad o su universalidad son las de la historia, en la que él es una fuerza activa y en la que se transforma, sin renunciar a su base conceptual. Su base es el análisis dialéctico del proceso histórico, del que se infiere la necesidad humana - no la «natural» - de transformar la sociedad (Marcuse, 1976, pág. 57)

Asimismo en gran error han incurrido quienes pretendieron hacer del marxismo un manual estático dentro de la historia que se puede validar atemporalmente, pero también sería un gran error alejar el pensamiento de Marx como herramienta posible en la comprensión de la 
realidad, en este sentido Marcuse analiza cuales son los conceptos que de Marx tiene vigencia y cuales exigen su superación histórica.

Pese a la evolución notoria del capitalismo desde el liberalismo producto de la revolución francesa y la revolución industrial hasta nuestros días, entre los hombres el valor de cambio prevalece sobre el valor de uso de las mercancías; por otro lado, toda satisfacción de las necesidades humanas se condiciona al excedente de ganancia que genera el trabajo;

...en la evolución del capitalismo, se desarrolla una doble contradicción: a) entre la productividad creciente del trabajo y el permanente incremento de la riqueza social, por un lado y su uso represivo y destructivo, por el otro; y b) entre el carácter social de los medios de producción (que no son instrumentos de trabajo individuales sino colectivos) y su propiedad y control privados; El capitalismo puede resolver esta contradicción solo temporariamente por medio del aumento del derroche, los gastos superfluos y la destrucción de las fuerzas productivas. (Marcuse, 1969, pág. 38)

En Marcuse hay cinco puntos concretos que colocan al marxismo como una teoría social en vigencia,a saber: 1. Predomina el valor de cambio sobre el valor de uso en las mercancías; 2. La prioridad de las sociedades capitalistas no se centra en la satisfacción de las necesidades vitales, sino que ellas pasan a un segundo plano; 3. A medida que se enriquece la sociedad y lo consigue a través de todas las formas la productividad aumenta, sin embargo, el control se sigue sujetando en pocas manos y su impacto en lo social dista mucho de ser social;

4. El capitalismo puede resolver esta contradicción solo temporariamente por medio del aumento del derroche, los gastos superfluos y la destrucción de las fuerzas productivas. 5. Solamente se puede romper este ciclo si las clases trabajadoras, que soportan el embate de la explotación, se apoderan del aparato productivo y lo colocan bajo el control colectivo de los mismos productores. (Marcuse, 1969, pág. 39)

Sin embargo, como ya habíamos mencionado, al ser el marxismo una ideología dialéctica su movilidad exige su propia actualización, es decir, si por un lado hay bases que manifiestan su actualidad, por otra parte hay conceptos que demuestran obsolescencia. 
En este orden de ideas, y una vez aclarado de manera somera los conceptos marxistas que prevalecen con utilidad a la lectura de la sociedad industrial avanzada, hay un punto que determina la urgencia por su actualización y que por ende pone de manifiesto las limitaciones actuales del marxismo si no se re-categoriza al contexto actual. En las sociedades de alto nivel industrial, y paulatinamente en las sociedades que se encuentran en vía acelerada de industrialización la tendencia es la pérdida de la negatividad que justificaba los procesos revolucionarios de finales del siglo XIX y principios del XX.

Hoy el sistema capitalista logró una aparente absorción del mismo modelo socialista, y en este punto hay que ser enfático en cuanto la evolución del capitalismo y el estanco del modelo socialista; por un lado el éxito del capitalismo hizo de la técnica su sustento permanente, lo cual exigió el avance de ésta misma, pero por el otro lado, a pesar de surgir como una teoría social y dialéctica, el socialismo eclosionó a sus raíces y se encerró en los paradigmas que fueron útiles para una sociedad revolucionaria, pero que se volvieron inútiles de cara a una sociedad industrial avanzada, permitiendo la acelerada integración del proletariado en el modelo burgués, en este sentido, el trabajador se convirtió en un pequeño burgués y sus ideales socialistas revolucionarios quedaron dominados por el mismo modelo capitalista.

Si bien la negatividad dentro del núcleo social, que es quien permite un proceso revolucionario dialéctico, es menos clara hoy que en cualquier otro momento de la historia, el control social continúa siendo monopolizado por pocos, así se genere el imaginario de acceso a los placeres que la sociedad industrial avanzada crea, y que satura a los individuos por todos los medios, la división entre dominantes y dominados es inexorable por las mismas condiciones que el capitalismo ha impuesto, con la diferencia que la imposición de hoy resulta hasta placentera e imperceptible para muchos respecto a la de décadas anteriores. Entonces:

... la sociedad capitalista se funda precisamente en su capacidad de absorber el potencial revolucionario, de liquidar la negación absoluta, y de sofocar la necesidad de un cambio cualitativo del sistema existente (...) La contradicción entre la riqueza social y lo que se hace 
con esta riqueza en los países capitalistas; es más grave que nunca, y precisamente por esto todas las fuerzas son movilizadas para ocultar ese contraste. (Marcuse, 1969, pág. 52)

Asimismo, han brotado desde las diferentes esferas sociales movimientos que han reclamado su posición concreta dentro de la sociedad exigiendo su reivindicación de derechos fundamentales, y si bien "estamos ante una sociedad clasista pero en la cual la clase obrera ya no representa la negación de lo que existe” (Marcuse, 1969, pág. 53), hay movimientos sociales que enriquecen la posibilidad de una negación; en este sentido la proliferación de estas nuevas demandas contribuyen a repensar la sociedad actual sin desconocer que la luchas de clases son el meollo de la dificultad.

El desvanecimiento de la clase obrera como negación latente y base de una revolución socialista ha dado lugar a una sociedad controlada desde los diferentes ámbitos que desde ella misma construye al punto que hay cierta satisfacción con lo dado, y sin embargo, a pesar de existir el problema coyuntural de poseedores y desposeídos el deseo de libertad ha sido remplazado por la misma civilización hasta la instancia que las luchas contemporáneas por la justicia social se han atomizado en diferentes subgrupos sociales donde el proletariado, cuyo trabajo enajenado sostiene el sistema, tiene frías manifestaciones, es más, el control del proletariado en las sociedades industriales avanzadas es casi nulo, y las esporádicas contradicciones de clase surgen en los países en vía de industrialización. "Este tipo de sociedad, lo repito, con su riqueza y con la concentración del poder político, militar y cultural, ha llegado a conseguir que la misma negación sea afirmativa, y en ella la necesidad parece desprovista de medios” (Marcuse, 1969, pág. 54).

La riqueza en la sociedad industrial avanzada depende cada vez menos del factor temporal del trabajo, por lo tanto el trabajador alienado ya no es agente activo en la producción sino que su desempeño se condiciona a la supervisión y regulación del proceso de producción. En este sentido entrar en contradicción dialéctica tal como la planteaba Marx, significaría que el producto dependiera más de la fuerza de trabajo del obrero, pero por el contrario, la riqueza en la sociedad industrial avanzada tiende de manera acelerada a una automatización en el proceso de producción. 
En este sentido retorna Marcuse bajo el referente de Marx. El proceso de división del trabajo ha generado la enajenación del hombre, empero, dicha ruptura esencial del hombre para representarse en un otro, llámese, máquina, capital, dios, etc., y entrar en función del mercado, si bien no es extraño al vivir de las sociedades contemporáneas, estas tienen en si marcadas diferencias frente lo cuestionado por Marx. "Los derechos y libertades que fueron factores vitales en los orígenes y etapas tempranas de la sociedad industrial se debilitan en una etapa más alta de esta sociedad: están perdiendo su racionalidad y contenido tradicionales" (Marcuse, 1985, pág. 31), la justificación de las nueva formas sociales se cimentaba en la razón, ahora esta racionalidad carece de razón, es decir, lo que antes se proyectaba como proceso inexorable de la razón del progreso, este mismo progreso ha olvidado su base racional.

Es claro que en la lectura que hace Marcuse de Marx salen a relucir deficiencias en la teoría de éste último, y no deficiencias por omisión sino porque la misma teoría pronosticaba su desactualización, es decir, al plantearse la lucha de clases como realidad dialéctica inmersamente ya se evoca a la movilidad y es desde allí que se debe re-prensar el mismo marxismo. Al poner el marxismo en el panorama actual de la sociedad industrial avanzada nos enfrentamos a realidades ajenas a las realidades de finales del siglo XIX, las realidades de aquella época se encontraban en un proceso revolucionario donde la contradicción entre burguesía y proletariado no permitían aproximación alguna, es decir, que dentro del contexto histórico la negatividad estaba latente y al estar de manera tan clara permitiría el ambiente revolucionario. Sin embargo dentro de la actualidad de la sociedad industrial avanzada el proletariado se ha aburguesado, entonces, al romperse la brecha evidente en décadas anteriores entre las clases sociales se pierde la posibilidad de la contradicción dialéctica y de igual forma se perderá la claridad de una negatividad, es así que ni siquiera podríamos afirmar que nos encontremos en estado pre-revolucionario, pues el proletariado se siente a gusto con lo que el sistema capitalista ha hecho de él.

La estructura dialéctico-histórica de la teoría marxista implica que sus conceptos cambian a medida que las relaciones básicas entre las clases hacia las que aquellos apuntan también lo 
hacen; pero ello se produce de manera que el nuevo contenido procede del desenvolvimiento de los elementos inherentes al concepto originario, con lo que la coherencia teórica e incluso la identidad del concepto se conservan. (Marcuse, El Materialismo Soviético , 1971, pág. 22)

La propuesta que desarrolla Marcuse a lo largo de su obra es retomar la dialéctica marxista, empero, esta tarea de por sí ya tiene componentes que el mismo Marx desconocía, y no por omisión, sino por el mismo devenir histórico. No es lo mismo referenciar a una clase trabajadora de mediados y finales del siglo XIX donde sus condiciones laborales impedían la satisfacción de sus necesidades primarias, y por lo tanto, su negación frente a la burguesía dominante era tan clara que las mismas realidades conducían hacía sociedades revolucionarias; a compararlas con las sociedades actuales donde la primacía por la satisfacción de necesidades básicas pasó a un segundo plano, y donde el hombre es presa del control de sus deseos por parte de la sociedades opulentas. "La concepción de la revolución en Marx se basa en la existencia de una clase pauperizada y deshumanizada, pero que al mismo tiempo estaba exenta de todo compromiso con el sistema capitalista y representaba, por consiguiente, una nueva fuerza histórica con necesidades y aspiraciones cualitativamente diferentes” (Marcuse, 1969, pág. 40).

Entonces debemos aproximarnos al marxismo de manera dialéctica, esto significa romper con estructuras dogmáticas que en torno a él se han forjado, para llegar a su esencialidad que es la misma libertad del hombre; en este sentido la crítica de Marcuse se hace enfática en torno al totalitarismo soviético, pues los alcances del modelo negaron lo fundamental de él mismo que es la consecución de la libertad, al terminar la segunda guerra mundial el enemigo occidental era el comunismo, ahora la cruzada era contra su herejía, que sería dirigida por los Estados Unidos de Norte América contra los soviéticos, situación que pondría en el imaginario del hombre común una desfavorable postura ante el socialismo, asumiendo que todo modelo socialista tendría la estructura del modelo totalitario soviético.

En este orden de ideas la negatividad se volvió en afirmación del mismo sistema, ahora las condiciones económicas no serían la evidencia de las brechas sociales, es más, estas mismas distancias entre una clase desposeída y otra poseedora parecían acortarse cuando el nivel de vida del mismo trabajador, que sigue siendo enajenado, sube dándole la Jairo A. González Moreno 
oportunidad de acceder a bienes de consumo que antes eran parte de la exclusividad burguesa, entonces lo que el socialismo debe replantearse es una mirada desde el hoy, y en este hombre inmediato y mediado que somos, esta no sólo una razón devaluada, sino un inconsciente donde habita el huésped predilecto del capitalismo : el deseo.

Asimismo es clara la contradicción que prevalece en la sociedad actual, por un lado las posibilidades intelectuales y materiales han alcanzado niveles sin precedentes, y por el otro, estas posibilidades que serían capaces de alivianar de problemas al hombre y a su sociedad no se direccionan a un final de las utopías donde lo ideal sea praxis, por el contrario hay una inversa proporción en esta contradicción entre los logros intelectuales y materiales y la dominación que la sociedad ejerce sobre el individuo.

\section{b) Freud: entre el principio de realidad y el principio de placer}

De acuerdo con Freud, la historia del hombre es la historia de su represión. La cultura restringe no sólo su existencia social, sino también la biológica, no sólo partes del ser humano, sino su estructura instintiva en sí misma (Marcuse, 1983, pág. 25)

Una vez aproximados a la obra de Marcuse es inevitable vernos conducidos a Freud, sin embargo, la pregunta que nos atañe no es la plenitud de la obra de Freud, además sería un monumental esfuerzo que nos desenfocaría de nuestro propósito primario, sino a la revisión de la relectura que Marcuse hace de ella y hasta qué punto se convierte en una propuesta ética que nos aproxime a una crítica de las sociedades actuales.

En la publicación de 1955 de Eros y Civilización encontramos los rastros fundamentales de la crítica que fórmula Marcuse a la teoría de Freud, empero, es importante señalar que dicha crítica no se establece como un derrumbe de las estructuras teóricas de la obra de Freud, sino como un reconstruir a partir de nuevas posibilidades. Dicha crítica se direcciona esencialmente a lo que gira en torno a la contradicción entre el principio de placer y el principio de realidad; Freud ya nos había planteado que dentro de la cultura se ejerce una presión al individuo que de manera casi perpetua y constante condiciona al hombre, sin 
embargo, para Marcuse no resulta del todo satisfactorio asumir con resignación la opresión que la civilización desarrolla, en este sentido hay una vertiente diferente del mismo cause.

El problema acá planteado en cuanto a temática no es novedoso dentro del pensamiento, basta con recordar el diálogo de Filebo de Platón o la obra de Epicuro, para evidenciar la contradicción entre el placer y la sabiduría, o si se quiere, en términos freudianos, entre el principio de placer y el principio de realidad, que en últimas son reflexiones éticas pues se convierten en medidas conductuales que encaminan a un proyecto de felicidad o de aproximación a ésta.

Quizás la felicidad no esté exclusivamente en el placer o en la sabiduría, sino que se situé en la mezcla como diría Sócrates, o se encuentre fuera del alcance humano porque en ésta lucha entre el principio de placer y el principio de realidad la represión es triunfante, nos diría Freud; pero en Marcuse, principalmente en Eros y Civilización, nos encontramos ante dos posibilidades novedosas que exigen la reflexión desde un presente: Por una parte examinar si es posible pensar una civilización sin represión perpetua de los impulsos naturales del hombre, y por otra pensar en un Final de la Utopía donde los medios técnicos nos conduzcan a formas avanzadas de libertad y en ultimas de felicidad.

Cuando nos referimos al principio de placer y principio de realidad nos aproximamos a dos categorías en constante lucha, una que intenta imponerse desde la exterioridad de hombre y la otra que pretende manifestarse desde la parte más interna de la psique humana. Para avanzar sobre el camino seguro en este propósito de evidencia de una ética en Marcuse dejemos que sea él mismo quien nos aproxime a ciertos conceptos fundamentales dentro de su obra:

\section{Principio de Realidad}

La suma total de las normas y valores que dominan en una sociedad dada, incorporadas a sus instituciones, traducidas en las relaciones humanas, etc.

\section{Principio de Rendimiento}


Un principio de la realidad que se basa en la eficiencia y en la capacidad de salir con éxito en la lucha competitiva.

\section{Sexualidad}

Instinto parcial; energía libidinosa que se limita y concentra en las zonas erógenas del cuerpo, sobre todo sexualidad genital (Marcuse, 1983, pág. 8)

La tesis del Principio de Realidad se enfrenta a su negación que es el Principio de Placer: en esta encrucijada dialéctica se encuentra el hombre. Todo individuo desde su nacimiento es sometido a una represión de su principio de placer, y ésta es una realidad que ha marcado la historia de la humanidad, sin embargo, la novedad que radica en las sociedades contemporáneas son los alcances de dicha sublimación. En palabras de Freud:

No es difícil reconocer la tendencia a que estos procesos primarios obedecen, tendencia a la cual hemos dado el nombre de principio de placer. Tienden a la consecución de placer, y la actividad psíquica se retrae de aquellos actos susceptibles de engendrar displacer (represión). Nuestros sueños nocturnos y nuestra tendencia general a sustraernos a las impresiones penosas son residuos del régimen de este principio y pruebas de su poder (Freud, 1993, pág. $630)$.

En este orden de ideas el individuo para entrar en las dinámicas de la civilización debe abandonar paulatinamente el principio de placer, es un principio que desde la etapa infantil y a través del padre y posteriormente desde la cultura se va reprimiendo y dejando en lo más profundo del inconsciente, pues como es natural el éxito de toda represión de la civilización es que se ubique en el inconsciente.

Pero por otra parte se encuentra el principio de realidad que se establece como la cara opuesta y racional del principio de placer, caras de una moneda que en últimas es el hombre, sobre él pesa más la represión racional y en consecuencia paulatinamente se sesgando más y más la satisfacción del principio de placer, de esta forma la frustración no se hace esperar y ante ella el aparato racional del Principio de Realidad entra a consolar con sus artefactos y aparatos sublimadores. 
La decepción ante la ausencia de la satisfacción esperada motivó luego el abandono de esta tentativa de satisfacción por medio de alucinaciones, y para sustituirla tuvo que decidirse el aparato psíquico a representar las circunstancias reales del mundo exterior y tender a su modificación real. Con ello quedó introducido un nuevo principio de la actividad psíquica. No se representaba ya lo agradable, sino lo real, aunque fuese desagradable. Esta introducción del principio de realidad trajo consigo consecuencias importantísimas (Freud, 1993, pág. 631).

Estas consecuencias importantísimas de las que nos habla Freud son el cuestionamiento que Marcuse entra a hacer de la conclusión de la tensión entre el Principio de Realidad y Principio de Placer que la teoría freudiana plantea. Si bien Marcuse acepta esta lucha, lo que niega es la aceptación pasiva del dominio del Principio de Realidad sobre el Principio de Placer. A manera de ejemplo y sin pretender aislarnos del tema en cuestión que es lo ético haremos una referencia arbitraria si se quiere a Aristóteles; cuando Aristóteles nos propone la teoría de las cuatro causas para la comprensión de un fenómeno dado entendemos que este elemento físico posee inevitablemente una causa material, una formal, una eficiente y una final, imaginemos ahora esta teoría para la compresión del hombre: naturalmente la discusión y ambigüedad caerá sobre lo que denominamos causa eficiente y causa final; tendríamos claridad sobre la causa material y la causa formal, pero cuando la pregunta se aproxima a la revisión de la causa eficiente encontramos notoria contradicción puesto que el hombre posee un aparato instintivo que lo hace ser conforme a su naturalidad, es decir, que manifiesta su eficiencia desde adentro hacia afuera, pero cuando examinamos la causa final evidenciamos que el hombre dentro de su finalidad resulta ser negación de su causa eficiente, pues su causa final es lo que está siendo producto del afuera dominador.

Dentro del principio de placer y el principio de realidad se encuentra el hombre, y en él su aparato psíquico complejo deriva en tres instancias, entonces, todo individuo que goce de un equilibrio mental es aquel donde de manera armónica habitan los tres sistemas freudianos de la mente: el id, el ego y el súper-ego (ello, yo y súper-yo), tal como lo plantea el mismo Freud estas instancias psíquicas determinan al individuo; "la base fundamental y 
más antigua y amplia, es el $i d$, el dominio del inconsciente, de los instintos primarios. El id está libre de las formas y principios que constituyen al individuo consciente, social" (Marcuse, 1983, pág. 44). En este sentido el $i d$, se manifiesta como la instancia amoral de la psique, mientras su lado opuesto: el superego es la estructura moral y normativa que es introducida por el padre y ulteriormente por la sociedad, y es en este sentido donde se estructura un condicionamiento moral, entre ellos dos (entre el id y el superego) habita el ego, quien excluye al principio de placer y que es quien gobierna sobre el id, para ubicarse en un lugar más seguro como lo es el principio de realidad, necesariamente más próximo a los cánones morales del superego.

Entonces el ego se desarrolla desde la represión que el principio de realidad ejerce sobre él, entendiendo que el éxito de toda represión es que se ubique en el inconsciente,la represión es histórica, es decir, que en determinado momento histórico se desarrollo de dada forma, dando diversas posibilidades al principio de realidad."El principio de la realidad sustenta al organismo en el mundo exterior. En el caso del organismo humano, éste es un mundo histórico. El mundo exterior enfrentado por el ego en crecimiento es en todo nivel una específica organización sociohistórica de la realidad, que afecta la estructura mental a través de agencias o agentes sociales específicos” (Marcuse, 1983, pág. 47).

Si bien la represión manifiesta facetas dentro del contexto histórico, la represión no necesariamente debería ser constante y menos aun, como lo ve Marcuse, tener una represión excedente, que garantice la eternidad represiva que el mismo Freud veía.Sin embargo, y de manera paradójica, mientras la sociedad genera una represión excedente, es decir, "las «modificaciones» de los instintos necesarias para la perpetuación de la raza humana en la civilización” (Marcuse, 1983, pág. 48);la civilización va abriendo puertas que moralmente antes mantenía cerradas, es decir y a manera de ejemplo, dentro de la racionalidad del principio de realidad el instinto de agresividad en tiempos pasados se reprimía de manera más evidente, hoy la misma civilización fomenta una agresividad en la lucha por la existencia en la que se someten los individuos, mientras el impulso libidinal controla el mercado fomenta su consumo. 
Asimismo, mientras el progreso se evidencia en la sumisión de la naturaleza a los pies del hombre, en la misma proporción la cultura somete al hombre, pues si el progreso es el dominio de la naturaleza, la misma naturaleza humana se va a ver condicionada como requisito del mismo progreso. "El progreso de la cultura, marcado por la represión adicional, e incluso, en vista de la creciente dominación de la naturaleza, marcado por una represión excedente relativamente creciente, debilitó el componente erótico y fortaleció el componente destructivo de la energía pulsional” (wiggershaus, 2011, pág. 625)

Por lo tanto, para Marcuse hay un resultado del proceso dialéctico que Freud no lograría percibir, pues en este último la represión tiene un carácter evidentemente biológico que excluye la síntesis que se genera dentro del individuo producto del triunfo de un superego moral. "La excesiva severidad del superego, que toma el deseo por el acto y castiga inclusive la agresión suprimida, es explicada ahora en términos de la eterna lucha entre Eros y el instinto de la muerte" (Marcuse, 1983, pág. 84), sin embargo, en Marcuse el instinto de muerte quiere triunfar sobre el Eros condicionado; si la misma vida se estructura como una constante de frustración, el instinto de muerte pretende aflorar ante la represión y ante esta represión surge una represión excedente, pues la civilización debe estar elevando los muros que encierran al individuo dentro del principio de realidad.

La civilización tiene que defenderse a sí misma del fantasma de un mundo que puede ser libre. Si la sociedad no puede usar su creciente productividad para reducir la represión (porque tal cosa destruiría la jerarquía del statu quo), la productividad debe ser vuelta contra los individuos; llega a ser en sí misma un instrumento del control universal (Marcuse, 1983, pág. 95)

Retornando al cuestionamiento que Marcuse intenta resolver a lo largo de Eros y Civilización, en cuanto si es posible una civilización no represiva, pues nos encontramos ante una respuesta afirmativa, los medios técnicos que el hombre ha construido hoy más que nunca darían la posibilidad de pensar una sociedad más justa, hoy como nunca antes la civilización ha llegado a unos niveles de progreso donde el trabajo no demanda de jornadas extensas y dentro de él hay una reducción de la fuerza que el individuo imprime al desarrollo de un producto dado, las riquezas alcanzadas podrían sacar de la pobreza a 
muchos sectores, etc., sin embargo, la lucha que se plantea acá por la libertad no debe enfrentar exclusivamente el principio de realidad desde su misma lógica racional, en este sentido retornaríamos a lo que Nietzsche cuestionó de Kant, en cuanto la imposibilidad de pensar en desarrollar una crítica a la razón a partir de la misma razón, en este sentido sería como al juez al juzgado simultáneamente.

En este orden de ideas las condiciones históricas se encuentran, empero, la civilización ha logrado generar aquella represión excedente de manera tan efectiva que la perdida de la libertad a través de la represión goza de gran efectividad. "Desde la rebelión de los esclavos en el mundo antiguo hasta la revolución socialista, la lucha de los oprimidos ha terminado siempre con el establecimiento de un nuevo, y «mejor», sistema de dominación; el progreso ha tenido lugar a través de una cadena de control cada vez más eficaz” (Marcuse, 1983, pág. 93). Si bien dicha cadena de opresión resulta cada vez más efectiva podríamos decir que dentro de este panorama oscuro y quizás pesimista la misma civilización construye sus propios demonios; el principio de placer cada vez va quedando en mayor represión bajo la exigencia y triunfo aparente del principio de realidad, esto significa que la ananké(lucha por la existencia) desata una confrontación del hombre contra el mismo hombre en búsqueda de su propia subsistencia enmarcado dentro de un super-ego hipermoralizado que a la par de la represión y la frustración va desarrollando un sentimiento de culpa, pues allí donde la represión excedente triunfa la culpa crece, en este sentido, el instinto de muerte intenta romper con lo establecido. "El trabajo del instinto de la muerte aparece, así, como el resultado del trauma de la frustración primaria: la necesidad y el dolor son proyectados aquí por un suceso geológico - biológico” (Marcuse, 1983, pág. 131).

Podríamos concluir que en Marcuse más allá de pensar en un triunfo del principio de placer, la lucha real es hacia la represión excedente del aparato libidinal, de la mano de Freud podemos afirmar que la ausencia total de la represión no es posible, en primera instancia porque entraríamos todos en una lucha ciega por la satisfacción de los instintos y en esta lucha por la felicidad sólo uno la alcanzaría bajo la premisa que sea prohibido matar; y en segunda instancia una sociedad alejada del principio de realidad crearía individuos incapaces de salir de una etapa infantil. En este sentido, si el principio de 
actuación, que es "la forma histórica prevaleciente del principio de realidad" (Marcuse, 1983, pág. 48), emana como su rebeldía ante la dialéctica de su civilización, entraría en confrontación con su mismo principio histórico de realidad, y es importante aclarar que dentro de la estructura de una sociedad represora la memoria se vislumbra como enemiga en tanto que cada recuerdo evocado de un principio de placer quiere aflorar y si el principio de actuación entra en lucha interna. "El principio de actuación fortalece la integración de una organización represiva de la sexualidad y del instinto destructivo" (Marcuse, 1983, pág. 126), entonces el principio de actuación se revelara ante su padre para que en aquella ananké su existencia sea fuera de la represión libidinal. 


\section{CAPÍTULO III}

\section{LA ÉTICA EN HERBERT MARCUSE}




\section{Introducción}

Una vez que determinamos someramente la génesis de la sociedad industrial avanzada y nos aproximamos a la dialéctica que propone Marcuse en su obra, hemos puesto en evidencia que a partir de la notable tensión que surge en la civilización, entre el Principio de Realidad y el Principio de Placer, emerge una propuesta por parte de Marcuse que ahonda en la ética de manera implícita y que nos vemos con la necesidad de dilucidar.

La lógica occidental nos encaminó por vías cada vez más lejanas de lo propiamente humano, aunque ante nosotros se manifieste la ilusión de una linealidad histórica placentera donde la satisfacción de las necesidades vitales pasa a un segundo plano siendo remplazada por estereotipos e imaginarios que hacen prevalecer las estructuras sociales vigentes, por lo tanto, en notable contradicción: los logros de la civilización han permitido facilitar como nunca antes la calidad de vida de muchos de los hombres, sin embargo, en la medida en que la civilización dota al hombre de comodidades y lujos reprime con mayor intensidad la fuerza libidinal, es allí donde surge la crítica de Marcuse y donde vamos desglosando el contenido ético de dicha crítica.

Hay que partir haciendo claridad que la crítica que genera Marcuse no es a la totalidad de la represión, pues mal haríamos en pretender liberarnos de toda ella, esto significaría devolvernos a un estado primitivo, la pregunta se enfoca es al por qué de una represión excedente, viéndose obligado el hombre a romper con ella; "el mismo individuo libre debe provocar la armonía entre la gratificación individual y la universal" (Marcuse, 1983, pág. 178), en este orden de ideas, divisamos un horizonte ético, si bien esta idea de armonía no nos resulta ajena cuando hacemos revisión de las reflexiones éticas de la filosofía antigua como el caso de Platón en el diálogo de Filebo, por citar un ejemplo, en Marcuse la armonía no debe determinarse entre la sabiduría y el placer, sino en la conciliación del principio de realidad y el principio de placer, es decir, en el alcance de una libertad real y humanista donde el individuo pueda disfrutar los alcances de los logros de su misma civilización, en consecuencia toda represión excedente debe finalizar. 
Cada vez que hacemos referencia a la ética tenemos que aproximarnos a conceptos de libertad e inexorablemente de dicha, sin embargo, es un profundo yerro pretender adoptar un concepto único de ética atemporal, esto significaría que nuestro concepto se sentaría sobre falsas bases y naturalmente se derrumbaría.

Como es sabido el pensamiento de Marcuse tiene profundos lazos teóricos con figuras de la filosofía como Hegel, Marx y Freud, fundamentalmente, y no como simple continuador de una filosofía propuesta por ellos sino como un dinamizador del movimiento dialéctico del pensamiento de estos personajes, esto quiere decir que al hacer referencia a un concepto ético desde Marcuse nos dirigimos a su concepción dentro de la historia, en palabras de Marcuse:

“... si se postula que efectivamente hay disponibles medidas y criterios racionales para juzgar de las posibilidades humanas de libertad y de dicha, entonces habrá que admitir que las unidades de medida éticas y morales son históricas” (Marcuse, 1970, pág. 143).

Por lo tanto, y tal como no lo hemos planteado, la primera instancia a la que debemos acudir es a la historia misma, para entrar en el inevitable juego dialéctico al que ella misma nos ha arrojado, sin embargo, no es ir a la historia como simples apologéticos de su realidad, acá la tarea es ir más allá de una realidad que no satisface y que cada vez cierra más las puertas a la libertad y a la dicha de sus hombres.

Ya Nietzsche nos había lanzado la alarma del riesgo que significaba hacer una crítica de la razón desde la misma razón o una crítica de la moral desde la misma moralidad:

Esta funesta contestación de Kant no nos ha conducido a los filósofos a un terreno más sólido y menos inseguro; pero, dicho sea de pasada, ¿no era un poco extraño pedirle a un instrumento que criticase su propia aptitud y perfección? ¿No era absurdo exigirle a la razón que ella misma calculara su valor, su fuerza y sus límites? Por el contrario, la verdadera respuesta hubiera sido que todos los filósofos, tanto Kant como los anteriores a él, han construido sus edificios sobre la seducción de la moral; que su intención sólo se encaminaba en apariencia a la verdad y a la certeza... (Nietzsche, 1994, pág. 29) 
Entonces, el camino hacia una reflexión ética de por si no es del todo claro, y si no miramos más allá de las estructuras que aparecen ante nosotros de vacua felicidad entraríamos una y otra vez en aquel torbellino de irracionalidad al cual la misma sociedad industrial avanzada nos ha lanzado, del que ni la misma filosofía se ha librado.

Ahora que hemos recorrido desde la génesis hasta hoy en día el trasegar de la sociedad industrial avanzada, y que a la vez hemos visto las contradicciones y tensiones que de allí mismo emanan, para llegar a la constitución del hombre contemporáneo, es fundamental para el movimiento dialéctico superar la absorción que el mismo capitalismo generó de sus contradicciones, y que al hacerlo vulneró la conciencia y la inconsciencia del hombre para ubicarlo unidimensionalmente dentro de un espacio - temporal donde predomina la ausencia de la libertad; donde el trabajo enajenado a pesar de establecerse en condiciones diferentes respecto a tiempos pasados continua limitando la voluntad; donde las necesidades vitales son superadas por necesidades que el mismo sistema ha ofrecido; donde las relaciones con los otros generan dependencia y rivalidad; donde esta vía unidimensional ha generado el mayor impacto que el hombre ha podido generar frente a su entorno natural.

Por tanto dentro de estos factores se desarrolla una propuesta ética que a lo largo de la obra de Marcuse se hace presente en un contexto de vigencia para la comprensión del comportamiento humano desde tres aspectos concretos indisociables: a) en primera instancia debemos aproximarnos a la relación del hombre consigo mismo, es decir, desde lo propiamente consciente e inconsciente de su individualidad; b) empero, las relaciones del hombre consigo mismo son permeadas por un mundo que el mismo forjo, en este sentido, debemos conducirnos a la indagación del hombre ante el otro, es decir, toda aquella estructura conductual que socialmente se constituye, y por último, c) al ser este un proyecto contemporáneo y más aún desde la modernidad un proceso de subordinación del hombre a la naturaleza, su impacto exige de la revisión del hombre frente a su entorno. Al examinar críticamente estos aspectos nos conduciremos al proyecto ético implícito que habita en la obra de Marcuse, y que se convierte en herramienta de análisis para el mundo actual. 
¿Cómo poder ubicarnos en la ética si ni siquiera hemos emitido un provisional concepto de la misma? A manera de boceto propondremos un horizonte que nos sirva de guía en nuestra tarea acá planeada; es pertinente recordar que quien elabora un boceto éste no es de por sí su obra final, sino que a partir de allí emprende la tarea de construcción y deconstrucción desde una base que en últimas quizás ni sea perceptible.

\section{Hacia un concepto de ética}

A qué hacemos referencia cuando hablamos de ética es la pregunta que nos sale al paso, aunque con normalidad y pretensión de conocimiento muchas veces nos referimos a ella simplemente como un conjunto de valores o reglas morales ignorando la profundidad de su concepto.

Los cuestionamientos, teorías y prácticas en cuanto a la ética han sido tema recurrente dentro de la historia de la filosofía, y no con ello podemos afirmar que el hombre se encuentre hoy día en la cima de un acumulado ético que a través de la historia ha alcanzado, por el contrario las actitudes humanas distan mucho de un ideal planteado desde la antigua Grecia donde la felicidad y libertad justificaban el proyecto de cada individuo en armonía con los otros y su entorno.

Si hacemos revisión cronológica detallada de la concepción de ética debemos volver, como casi siempre nos pasa en el mundo occidental, a los griegos.

La ética dentro de la historia de la filosofía ha sido una constante reflexión en torno a la pregunta por el actuar del hombre; actuar que inexorablemente debe entrar en una dialéctica coherencia respecto a su contexto histórico y la concreción de su felicidad, para así avanzar en el proyecto de humanización. En este orden de ideas, plantearse un cuestionamiento de la ética a partir del contexto histórico en el cual se desenvuelve el hombre es la tarea primera de la ética - filosófica.

El devenir del hombre en su mundo constituido del cual paulatinamente cree y pretende entender, unos en mayor medida que otros, pero al fin de al cabo un mundo que se 
comparte en un aquí y en un ahora exige revisar aquellas categorías que sujetan al hombre condicionándolo a actuar de determinada manera y que de forma casi que imperceptible teje los proyectos de felicidad de una gran mayoría sumiéndolos en la más onda vacuidad.

El camino hacia la ética se torna aún más escabroso cuando ella se condiciona a una moralidad que en apariencia y conveniencia resulta ser más estática que la misma ética, y esto cuando se hace medianamente perceptible una diferencia, porque en gran medida hablar desde el hombre común tanto de ética como de moral es mentar un mismo concepto, entonces en el mundo de la ingenuidad, es decir, el mundo más cercano, se cree que quien obedece a unas estructuras morales rígidas y en el mayor de los casos atemporales asume una vida ética, empero, la ética determina la libertad misma y hace revisión de la moral normativa que se imparte, por lo tanto acá nos hallamos ante una pregunta fundamental ¿Quién dictamina lo que moralmente es bueno o malo? y de serlo así ¿Cuál es el papel liberador de la ética? Si nos acercamos sólo a manera de ejemplo dilucidador a la figura de Robín Hood determinaríamos con mayor claridad las distancias entre ética y moral. Ante la sociedad actual, y aún más la medieval donde surge la leyenda de éste personaje, moralmente el robo es condenado social y culturalmente como lo "malo", sin embargo, en la leyenda de Robín Hood encontramos un hombre que falta a la moral establecida para asumir por vías éticas su ideal de lo justo, desde su profunda autonomía y libertad actúa con parámetros ajenos a la moral de lo "bueno", empero, sería gran error pretender que la sociedad sea amoral, acá la tarea es la ya planteada por Nietzsche, la de construir una nueva moral para un nuevo hombre, una moralidad donde todos los individuos la acepten no por una sumisa obediencia sino bajo el consenso que la misma libertad permite.

En este orden de ideas "La ética busca un autocontrol de la conducta humana posibilitado por un proyecto humano realizador que permite al individuo ser feliz" (Botero, 2007, pág. 221); a partir de la definición acá propuesta por Darío Botero Uribe podemos comprender que no es lo mismo el autocontrol a la represión, dentro de la ética el hombre es consciente de su actuar desde su más profunda esencialidad, pues él conoce el por qué de su actuar y no actúa simplemente bajo la represión excedente que es útil a una estructura políticoeconómica, por tanto el hombre ético asume un proyecto de felicidad libre y armónico consigo, con los demás y su entorno. 
Si el propósito de la ética es conducir al hombre a una felicidad realizable, tendríamos que acercarnos a lo que entendemos por felicidad. Podríamos afirmar que hay pocas condiciones más humanas que la búsqueda de la felicidad ( $v \dot{\delta} \delta \alpha \mu o v i ́ \alpha)$. Si cada sujeto se encamina a la felicidad como plenitud del ser, es decir, de la existencia, su caminar no es un andar a tientas esperando llegar a un feliz destino, sino un vivir existiendo, siempre en la armonía de su entorno.

Si muchas ciencias dentro de sí exigen la exactitud, asimismo lo hace la ética, el correcto actuar no obedece a momentos, la ética es una praxis constante y cuidadosa, si bien es de esencia individual su realidad está en la proyección social, si Platón hacia énfasis en la idea del bien como realización armónica de los hombres, dicha armonía se fracturaría a la menor variación, es por ello que Gadamer nos recuerda que el éthos es acertar exactamente, y éste acertar exactamente es una manifestación de autocontrol:

...en el ámbito del éthos, lo que tiene a la vista es «lo exacto mismo», ello quiere decir, evidentemente, que precisamente ahí lo importante es acertar exactamente, porque la aplicación del saber «puro» de la matemática no basta donde lo importante es acertar exactamente. Así ocurre manifiestamente, con la armonía, la consonancia, la belleza. En estas cosas, de hecho, el menor desvío ya es malo. (Gadamer, 2006, pág. 289)

Por tanto, el autocontrol se manifiesta no como cohesión de la libertad, sino por el contrario, es la libertad de elegir, ver más allá de lo propiamente individual donde la armonía reine como estatus de felicidad. En este sentido Botero Uribe nos dirá que: "La ética parte de construir una armonía entre la particularidad del mundo de un individuo y la universalidad de un mundo social que él aprende a reconocer”. (Botero, 2007, pág. 221), y este reconocimiento del mundo social sólo es realizable cuando se libere del hombre lo que la represión excedente a condicionado en él.

Entonces la ética al no ser una, pues su condición dialéctica la hace cambiante, nos exige enfocarnos en una que delimite nuestro planteamiento y en consecuencia nos lleve a una dilucidación de una ética en la obra de Herbert Marcuse; mal haríamos en buscar en las tinieblas algo, de ser así solo encontraríamos sombras y estructuras amorfas, pero para ir por un camino más seguro debemos enmarcarnos dentro de la Sociedad Industrial 
Avanzada y la ética que entre en negación con dicha sociedad, es decir, que nos encontraremos delimitados por un ideal ético práctico para el contexto actual.

Ahora bien, para un contexto actual qué debemos determinar para pensar la ética como negación de la sociedad reinante: Romper con toda forma de enajenación que limite la libertad del hombre, identificar los mecanismos de coherente armonía del hombre frente a sus semejantes al igual que con su entorno, entonces la ética debe procurar la libertad y dicha posible para cada hombre pero a su vez esta debe propiciar una relación justa entre los hombres y estos frente a su entorno.

Ahora que hemos emitido provisionalmente un concepto de ética, a partir de él seguiremos el rastro de la ética en Marcuse.

\section{La ética en Herbert Marcuse}

Cuando nos acercamos al pensamiento de Herbert Marcuse debemos mirarlo desde el contexto en el cual se desarrolla, es decir desde las más diversas influencias que impactaron su filosofía, pues naturalmente pensamos lo que el contexto nos hace pensar, y entender a Marcuse es mirar con los ojos de sus vivencias, así sea una aproximación subjetiva.

Que Marcuse naciera a finales del siglo XIX en Berlín el 19 de julio de 1898 ya es un indicativo de los hechos históricos que directa o indirectamente impactaron su vida, como lo fueron las guerras mundiales, el ascenso de los totalitarismos, la Guerra Fría, y el dominio de la sociedad opulenta en el mundo; proveniente de una familia judía burguesa. "En 1922 realizó su doctorado en Friburgo con una tesis doctoral Der deutsche Künstlerroman [la novela artística alemana]" (WIGGERSHAUS, 2010, pág. 127) . Marcuse después de recibir clases de Husserl retorna a Friburgo para convertirse en asistente de Heidegger donde la influencia de la fenomenología husserliana y de la obra de Heidegger principalmente de Ser y Tiempo ahondarían en el corpus filosófico de Herbert Marcuse; a principios de la década de los 30 la influencia de Marx en la obra de Marcuse es inminente, el marxismo tendría una nueva mirada que de la mano del Psicoanálisis freudiano y sumada a la juiciosa lectura de Hegel establecería los pilares de su obra. Algo 
determinante en el desarrollo intelectual de Marcuse fue su participación en el Institut für Sozialforschung [instituto de investigación social] que había llegado a Estados Unidos en cabeza de Horkheimer, desde allí Marcuse (1934) establece su crítica aguda a la sociedad opulenta y publica sus obras más reconocidas Eros y Civilización 1955 y El Hombre Unidimensional 1964.

En este orden de ideas y citando de manera muy superficial los aspectos que van a determinar el pensamiento de Marcuse encontramos como este cumulo de factores se evidencian a lo largo de su obra.

Ya en materia propiamente ética, en Marcuse es posible identificar con claridad dos elementos que conjuntamente estructuran su postura ética: la libertad y la dicha como necesidad en los hombres y sociedades actuales, quizás en tiempos pretéritos la ética tendría estas dos categorías idealizadas en un marco utópico, pero en Marcuse esta utopía puede llegar de una manera general a su fin, pues los alcances técnicos de la Sociedad Industrial Avanzada nos podrían conducir por caminos más positivos a los cuales haremos referencia a lo largo del texto.

Sólo podemos hablar de ética en la medida que las condiciones históricas permiten garantizar la armonía del hombre consigo mismo, con los otros y con su entorno dentro del marco de la libertad y la dicha alcanzable dentro del contexto del proceso histórico. Para Marcuse la libertad y la dicha no parten de la especulación de una moralidad estática en el tiempo y en el espacio sino de la realidad existencial de cada individuo; en la medida que el tiempo se dinamiza el hombre crítico entra en constante revolución ante el statu quo para reclamar la libertad y la dicha que pretende y puede alcanzar dentro determinado contexto histórico, es decir, que la exigencia de una idea de libertad y dicha que se plantee hoy debe entrar en nueva revisión dialéctica para un mañana, así desde el contexto este la pretensión que estos niveles de libertad y dicha hayan alcanzado su máximo esplendor determinando un final de la historia, afirmación que de la mano de Marcuse nos oponemos vehementemente: "La libertad humana no es un estado estático y nunca ha sido tal, sino que es un proceso histórico que incluye la alteración radical y hasta la negación del modo de vida establecido" (Marcuse, 1970, pág. 147). 
Asimismo, la ética como condición esencial del hombre crítico debe obedecer a éste mismo ritmo dialéctico propio de la historia; en este juego dialéctico la ética es filtro de la constante contradicción a la que se enfrenta el principio de realidad establecido, entonces, la tensión entre el principio de realidad y el principio de placer es competencia ética en la medida que el hombre a través de su accionar genera la negatividad (principio de placer), de la afirmación establecida (principio de realidad). En este sentido, la tensión inexorable del principio de realidad y principio de placer se desencadena a partir de la práctica ética, no con la intensión de someter el principio de placer al principio de realidad, o viceversa, puesto que el dominio del uno sobre el otro nos conduciría a una lucha a muerte por la libertad y dicha que pocos podrían alcanzar, sino con la intención de ganar la libertad y dicha posible para los hombres dentro de una armonía práctica humanística.

Tal como podemos apreciar en la siguiente gráfica la ética emana del diálogo entre el Principio de Realidad y Principio de Placer, diálogo que sólo se puede dar dentro de la historia y que requiere de puntos de quiebre que el mismo actuar del hombre (praxis ética) moviliza a nuevas posibilidades dialécticas. 


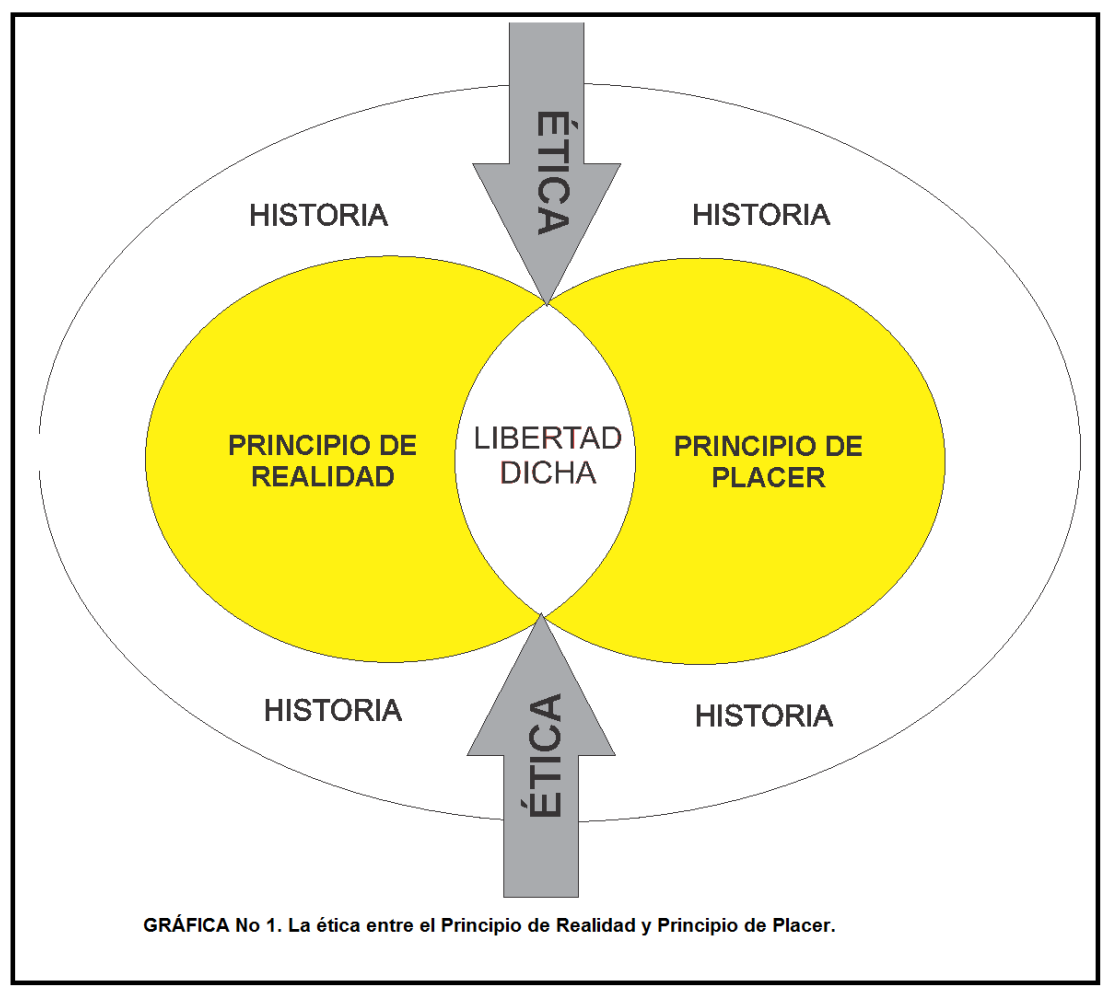

Ya hemos mostrado como la ética nace de la armonía entre el principio de realidad y el principio de placer, ahora, junto a Marcuse intentaremos poner dicha ética en términos individuales, sociales y ambientales.

\section{a) La ética individual}

Hay dos obras fundamentales en la literatura de Herbert Marcuse, entenderlas como complementos indisociables es fundamental a la hora de acercarnos a su pensamiento. Por una lado Eros y Civilización (1955) y por el otro lado El hombre Unidimensional (1964); a lo largo de esta casi década entre una y otra hay una conexión dialéctica que el lector desprevenido no alcanzaría a evidenciar. Ya hemos afirmado en líneas anteriores los vínculos estrechos que habitan en la obra de nuestro pensador con Hegel, Marx y Freud fundamentalmente, sin negar a Nietzsche, Heidegger, Husserl, entre otros que son perceptibles a lo largo de sus escritos, pero hacemos referencia a estos tres primeros en la medida que su pensamiento dialéctico enmarca el periodo entre Eros y Civilización y El Hombre Unidimensional, en dicho lapso entre una obra y otra hay un trasegar de lo 
particular a lo universal, parte Marcuse de la parte más primitiva del aparato psíquico del hombre hasta poner en evidencia como el sometimiento del principio de placer ante el dominio del principio de realidad establecen una sociedad unidimensional.

El Hombre Unidimensional se constituye en el momento que la represión excedente actúa sobre el hombre común, pero para llegar a esta unidimensionalidad el sistema se ha introducido en su aparato psíquico y ésta introducción se hace de la manera más democrática posible, pues el principio de realidad permea a toda la sociedad de manera homogénea, quizás la distribución del trabajo, de las riquezas y el goce no llegue por igual a todos los hombres, empero, la represión si se introduce a todos con impactos semejantes, pues en la sociedad unidimensional los hombres ven lo mismo, creen en lo mismo, dicen lo mismo, actúan igual, etc., y la libertad y la dicha posible de cada hombre queda en entre dicho y a él poco o nada parece interesar.

Sabemos que la libertad es el pilar de cualquier ética real, en este sentido toda la obra de Marcuse es una directa denuncia a la perdida de las libertades dentro de la Sociedad Industrial Avanzada y de manera indirecta es una propuesta ética.

Si bien hemos podido empezar a esclarecer el devenir de la ética dentro de la historia ahora nos toca emprender la tarea de establecer las categorías que a ella competen. La historia que nos ha conducido por vías cada vez más estrechas ha forjado un hombre unidimensional cuya posibilidad existencial sólo se concreta bajo la supervisión del sistema, en este sentido lo económico ha hecho mella en las estructuras éticas del hombre, por una parte, el hombre ha entrado en estado de comodidad dentro de las estructuras dadas, estado que sólo es propiciado por el deterioro de su capacidad de razonar libremente, es más, la imposición de los estereotipos le resulta ahora placentera; el hombre común se entiende a sí mismo como un ser libre en la medida que puede satisfacer sus impulsos de consumo en el mercado y adquiere cierto status de burguesía, es decir, ahora el anhelo de ser burguesía se endulza con la adquisición del artefacto, el hombre cada vez es menos libre, lo cual significa que sus reflexiones éticas distan mucho de la realidad, "la sociedad no ha ampliado la libertad individual, sino sus maneras de controlar al individuo" (MARCUSE, 1970, pág. 112); pero por otra parte, no sólo es la pérdida de libertad de ser el hombre lo que quiere ser, sino que los recursos técnicos con los cuales la Sociedad Industrial 
Avanzada cuenta se distribuyen cada vez más antidemocráticamente, entonces lo que se vislumbraba como un progreso común y justo desde hace un par de siglos hoy sólo se manifiesta en la realidad de pocas manos, más significativo aún es la contradicción que Marcuse nos ha manifestado: "Hoy podemos convertir el mundo en un infierno; como ustedes saben, estamos en el buen camino para conseguirlo. También podemos transformarlo en todo lo contrario" (Marcuse, 1986, pág. 7).

La pregunta ahora es cómo romper con el dominio si por un lado la técnica del hombre dentro de la historia ha permitido la consecución de niveles de vida antes insospechados de libertades y de disfrute que las condiciones históricas pasadas no lo permitían alcanzar, por otro lado, estas libertades y disfrute de la vida misma se fue concretando en pocos, la técnica ha avanzado a ritmos cada vez más acelerados, sin embargo, parece constituirse la ciencia y la tecnología en estructuras de control y dominio al establecerse en herramientas de la liberación, entonces:

Hoy es preciso responder a la cuestión de si la ciencia, en la "sociedad opulenta", no ha dejado de ser un vehículo de liberación, de si no perpetúa e intensifica la lucha por la existencia (a través de la investigación para la destrucción y de la atrofia planificada) en vez de mitigarla. (Marcuse, 1972, pág. 116)

Cada vez que el hombre entra en estado consciente de su vida y de los niveles de libertad y dicha que puede alcanzar se entiende como un ser ético, esto quiere decir que en la autonomía el hombre construye para sí, en armonía con sus semejantes y su entorno. Una vez alcanzado el nivel de consciencia más alto el hombre visualiza los excedentes de la represión que condicionan su vida e inexorablemente debe entrar en estado de revolución pues debe revelarse contra todo aquello que el Principio de Realidad ha colocado de más sobre los instintos vitales; toda ética es una revolución y toda revolución que parta de la ética es una negación contra lo que limita la libertad y la dicha. Asimismo podríamos afirmar que pese a que el trabajo no tiene las condiciones visualizadas por Marx en el siglo XIX la enajenación sigue imperando por lo tanto: "Objetivamente, "en sí", la clase trabajadora es todavía, potencialmente, la clase revolucionaria; subjetivamente, "para sí", no lo es" (Marcuse, 1969a, pág. 24). Esto quiere decir que la conciencia de estado de enajenación por parte del obrero se ha difuminado, pese a ser la mayor fuerza 
revolucionaría, más no la única, ha caído bajo el dominio del sistema quien desde el aparato psíquico ha derrotado al trabajador. Así: "El progreso capitalista, así, no sólo coarta el medio ambiente de la libertad, el "espacio libre" de la existencia humana, sino también la "aspiración", la necesidad de tal medio ambiente". (Marcuse, Un Ensayo sobre la Liberación, 1969a, pág. 26).

¿Entonces cual es la propuesta ética de Marcuse ante el hombre unidimensional? Como ya es sabido Marcuse se aleja de Freud en la medida que éste asume con resignación la imposición de la represión, por el contrario en Marcuse hay un optimismo ante la posibilidad de romper con la represión excedente pues las condiciones sociales hoy más que nunca propician técnicamente la manera de dar fin a la injusticia social, empero, aquí se exige un despertar que esencialmente es ético, en el momento en que el hombre se entienda como ser libre empezará la defensa por su libertad, una libertad consiente desde el trabajo, la cultura, la sexualidad, etc., es por ello que el hombre aislado no logrará la puesta en negación necesaria para el movimiento histórico, en este sentido, el hombre depende del otro que necesariamente ha sido también reprimido.

\section{b) La ética social}

Tal armonía entre el individuo y la sociedad sería muy deseable si ésta ofreciese a dicho individuo las condiciones para su desarrollo como ser humano, de acuerdo con las posibilidades disponibles de libertad, paz y felicidad (lo que está en consonancia con la posible liberación de sus instintos de vida), pero resulta muy destructiva para el individuo si no prevalecen esas condiciones. (Marcuse, 1981, pág. 107)

Ahora inexorablemente nos fijaremos en la sociedad unidimensional, no es un hombre particular al cual la fuerza del principio de realidad ha condicionado, sino de igual forma y de manera indiscriminada la represión excedente ha llegado a todo individuo, por tanto la sociedad unidimensional es la manifestación homogénea de la represión sobre los hombres, 
y como sociedad comienzan a tejerse diferentes grupos sociales demandantes desde diferentes esferas de su libertad, Marcuse entiende que en la sociedad potencialmente revolucionaria no está en un individuo que heroicamente salvará a sus semejantes, sino en las exigencias que desde diversos movimientos sociales nazcan producto de la presión y represión sobre algunos.

Es conocimiento de todos los que de cierta forma tienen proximidad al mundo académico la influencia que Marcuse marca en el desarrollo de estos movimientos sociales, e inclusive se señala como el guía ideológico de las protestas estudiantiles de Francia de finales de la década de los sesentas, situación que explica el horizonte del pensamiento ético en Marcuse; acá la exigencia es una exigencia ética de libertad no sólo en los movimientos estudiantiles, sino de igual forma en los movimientos feministas, de diversidad sexual, ambiental, étnica, etc., la gran virtud de Marcuse fue plantear desde una actualización de marxismo un movimiento más amplio capaz de cobijar a los históricamente silenciados, sin desconocer que el proletariado es el agente revolucionario por excelencia, al no ser ya el obrero el único excluido del sistema la negación del principio de realidad reinante comienza a dar desconectados pálpitos de rebelión.

Ahora la sociedad tiene en sus manos confort que le era exclusivo a la burguesía en tiempos anteriores y a pesar de ello su libertad está mayormente restringida, sin embargo, la satisfacción de las necesidades vitales cuando mayor goce podría tener hoy son reprimidas con mayor fuerza generándose una relación proporcional entre la represión y la moralidad: mayor represión - más normatividad axiológica.

Es inevitable que la angustia existencial haga presencia cuando el hombre se ve a sí mismo como una hoja a la deriva con la que el viento juega, sin embargo, hay que percatarse de ello para que ocurra tal angustia; pese a un malestar interno de insatisfacción que esporádicamente hace presencia en la vida del hombre actual factores externos generan la ilusión de felicidad en la cosificación de su vida, a pesar que el trabajo otorga mayor tiempo para el ocio su vida se encuentra anclada a una misma estructura de represión que ha extralimitado su fundamento. Si bien la civilización ha sobrepasado los niveles jamás 
antes vistos de represión su fruto ha favorecido en igual proporción el esquema de la sociedad industrial avanzada, en estos procesos históricos las crisis del hombre son remediadas desde la misma enfermedad; jamás la depresión, como en nuestras sociedades industriales ocurre, ha hallado su placebo tan efectivo en la misma fuente de su malestar, pues el vacío existencial es llenado con el mismo consumo que impulsa el sistema, es decir, dentro de la lógica inconsciente de los hombres que desprevenidamente se convierten en piezas de un todo permanece la sensación de alivio dentro de la misma represión, no importa si la vida miserable que se lleva internamente impide la felicidad siempre y cuando se obtenga recompensa placentera en las imposiciones sociales, en este sentido hay una desproporción entre las necesidades vitales y las que no lo son:

Las únicas necesidades que pueden inequívocamente reclamar satisfacción son las vitales: alimento, vestido y habitación en el nivel de cultura que esté al alcance. La satisfacción de estas necesidades es el requisito para la realización para la realización de todas las necesidades, tanto de las sublimadas como de las no sublimadas (Marcuse, 1985, pág. 35)

En Marcuse el actuar ético del hombre no es un ideal utópico, por el contrario considera que si bien el hombre ha logrado cohibir su libertad y la de los demás dentro de la manipulación de un sistema económico aun hay punto de salvación donde el equilibrio gobierne las actitudes humanas, es allí donde la cultura juega un papel fundamental y casi contradictorio ante la civilización, entonces si hacemos fomento de la ética como una realidad debemos establecer su práctica desde la cultura, en este sentido ¿Qué entendemos por cultura?

... "cultura" se refiere a cierta dimensión superior de autonomía y realización humana, mientras que "civilización" designa el reino de la necesidad, del trabajo y del comportamiento socialmente necesarios, en el que el hombre no se halla realmente en sí mismo y en su propio elemento, sino que está sometido a la heteronomía, a las condiciones y necesidades externas. (Marcuse, 1972, pág. 93)

La cultura es el camino a la humanización donde colectivamente se protege la vida y colectivamente se crean las herramientas de concreción de las expectativas de libertad y dicha que son propias a los hombres, desde la cultura es menester que la humanidad 
recupere lo propiamente humano y rompa con las cadenas del domino que han venido acorralando a los hombres por más de dos siglos, son pocas las cosas de la naturaleza humana que aun existe entre nosotros:

En realidad, la dimensión artística parece haber sido el único verdadero hogar del individuo, el único lugar en que el hombre podía ser un individuo tanto en su existencia material como en su existencia inteligible: no solamente como hombre interior, sino como hombre exterior (Marcuse, 1972, pág. 64)

En el arte la reflexión creativa del mundo hace presencia y lo hace como propuesta liberadora, en el arte hay reflexión ética en la medida que rompe con el principio de realidad aunque este último pretenda adueñarse inclusive de la dimensión estética e imponer el ideal de lo bello, cada vez que el arte se manifiesta libremente hay un trasfondo ético que lo hace anunciarse re-valorando lo que moralmente hemos dictaminado como bueno o como malo. Si pudiéramos situar una ética en Marcuse esta debería de salir de la dialéctica entre el principio de Realidad y el Principio de Placer y a su vez debería ésta ética entrar a valorar los juicios morales que se han aceptado que pertenecen más a un Principio de Realidad. En la medida que se hiper-moralise el Principio de Placer será dominado y el hombre se verá más condicionado a aceptar la represión excedente, pues:

Fundado en su propia razón y en virtud de ella, el individuo abandona las pretensiones sin compromiso del Principio de Placer y se subordina al dictado del Principio de Realidad, aprende a mantener un precario equilibrio entre "Eros y Thanatos", aprende a abrirse camino en una sociedad (Freud utiliza el término Cultura) que es cada vez más incapaz de hacerle feliz, es decir, de satisfacer sus impulsos. (Marcuse, 1970, pág. 96)

Si bien a la ética le interesa hacer una valoración constante de la moralidad que la circunscribe en la actualidad, la ética resulta mucho más dinámica dentro del marco histórico, haciendo parecer a la normatividad moral como un conjunto de leyes atemporales y divinas, y por ende incuestionables. La libertad debe ser la guía que conduzca a una nueva estructura moral donde la aceptación del conjunto axiológico sea por ella y no pese a 
ella misma, si bien reconocemos los fundamentos de una libertad desarrollada desde finales del siglo XVIII somos incapaces de reconocer la libertad esencial de cada individuo y mientras esta libertad no florezca alejada de la represión excedente sólo tendremos una idea de libertad que fomenta y perpetua el stau quo. "Estamos ante el problema de toda ética, a saber, ante la pregunta acerca de la sanción, en última instancia, de valores morales. O, dicho de modo más simple: ¿Quién o qué determina y decide la validez de las normas morales?" (Marcuse, 1970, pág. 150).

En este sentido pareciera que la moralidad ha sido tarea de pocos quienes se han valido de sofismas para poder introducir en el dominio a la gran mayoría. La ética de la revolución se muestra como una necesidad de libertad, la función ética del ahora es entrar en la consiente realidad de dominio y revelarse ante esta, no desde un frente sino desde los más variados y posibles sectores victimas del dominio, ahora la ética debe fomentar la revolución donde se dignifique la lucha de género, el medio ambiente, el indio, el negro, etc., y por supuesto el movimiento obrero que ha permanecido en un silencio sepulcral en el último siglo.

Dentro del mundo de la ética debemos afirmar que se entrelazan interdependientemente conceptos de libertad y dicha, y en ellos habita la realidad de un hombre que pretende ser feliz dentro imposiciones que constantemente lo frustran. "Hasta ahora, los hombres se han formado siempre ideas falsas acerca de sí mismos, acerca de lo que son o deberían ser” (Marx, 1968, pág. 11); es entonces tarea esencial romper con esas ideas falsas que entorno a nosotros mismos forjamos, y es allí donde la ética se muestra su pertinencia en la armonía social cuyo punto de partida es el reconocimiento del ser dentro de un espacio - temporal. Dentro de estas ideas falsas prevalece el irracional racionamiento entre un proyecto de felicidad impuesto y lo que los hombres comunes realmente pueden acceder, en este sentido, resulta, en términos de Marcuse obscena:

Esta sociedad es obscena en cuanto produce y expone indecentemente una sofocante abundancia de bienes mientras priva a sus víctimas en el extranjero de las necesidades de la vida; obscena al hartarse a sí misma y a sus basureros mientras envenena y quema las escasas materias alimenticias en los escenarios de su agresión; obscena en las palabras y sonrisas de 
sus políticos y sus bufones; en sus oraciones, en su ignorancia, y en la sabiduría de sus intelectuales a sueldo. (Marcuse, Un Ensayo sobre la Liberación , 1969a, pág. 15)

El siglo XX exigió a los pensadores de la época alternativas creativas para salir de la crisis que la racionalización había favorecido, pues lo que habíamos hecho del mundo no era la promesa establecida desde la modernidad, el ego cogito había negado al otro en cuanto no era justificación razonable de la existencia, tampoco lo era un empirismo donde recae nuevamente sobre el yo la condición de experimentar; de igual forma con el idealismo alemán el sujeto al subordinar el objeto determina en consecuencia su moralidad estableciéndose el imperativo categórico kantiano como el ideal consciente de lo bueno, sin embargo, ésta idea de lo bueno como producto de la razón de igual forma restringiría las libertades humanas en tanto la moral es producto de la razón y no de la voluntad del hombre como lo plantearían Schopenhauer y Nietzsche; sobre este andamiaje de hipocresía moral el siglo XX se constituiría como la negación a toda moral que vacuamente fue establecida.

Si bien el siglo XX desató la peor crisis ética y moral hasta nuestros días mal haríamos en señalar esta crisis como algo ajeno a los siglos predecesores, empero, dicha crisis puso ante los ojos de la filosofía retos que fueran capaces de apaciguar los límites del mismo hombre puesto que no sólo la libertad ha quedado en cuestión sino la misma vida ha sido desvalorizada. "Si consideramos que la vida humana, bajo todas las condiciones, es "per se" algo sagrado, entonces la distinción no tiene sentido y tenemos que admitir que la Historia es "per se" amoral e inmoral, porque nunca ha respetado ese carácter sagrado de la vida humana”. (Marcuse, 1970, pág. 153). Si el respeto a la vida humana ha quedado en un entre dicho moral a lo largo de la historia, la alarma sería más fuerte cuando demostramos que somos capaces de acabar el mundo, sin embargo el siglo $\mathrm{XX}$ a pesar de sus perversas manifestaciones con Guerras Mundiales, ascenso de totalitarismos, Guerra Fría, etc., gozaba de una irónica contradicción, pues colocaba la muerte como política fundamental de las potencias pero a su vez defendía las libertades, jamás los hombres habíamos sido tan libres externamente, pero jamás tan encadenados interiormente. 
Los medios de comunicación de masas fomentaron los odios entre razas, elevaron a dictadores a categorías mesiánicas, establecieron la felicidad dentro del consumo, hicieron de la violencia de género un espectáculo, justificaron el deterioro ambiental, pero a su vez mostraban al mundo libertades que antes eran impensables alcanzar. "Esta contradicción puede resolverse si entendemos que la liberalización de la moralidad propia del sistema establecido se realiza dentro del marco de controles efectivos; mantenida dentro de este marco, la liberalización fortalece la cohesión de la totalidad” (Marcuse, Un Ensayo sobre la Liberación , 1969a, pág. 17). En este sentido el mismo sistema ha controlado inclusive la revolución; la revolución sexual durante el siglo XX era un atentado contra la moralidad pasada pero si ella abanderaba la libertad que el sistema proponía bienvenida en términos comerciales. "La moral sexual se ha liberalizado en alto grado; aparte de esto se difunde la sexualidad como estímulo comercial, como puesto activo en el negocio, como símbolo de un nivel de vida" (Marcuse, 1970, pág. 111). Ahora la sexualidad salía de la esfera privada a la esfera pública, el voyerismo se arraigaba en los hombres del siglo XX hasta nuestros días, no sólo en términos sexuales sino en todos los ámbitos donde el hombre pudiera ver como un espectador ajeno a la realidad las guerras, las migraciones, el deterioro ambiental etc.

Ante este panorama bastante turbio de la historia Marcuse no ve con fatalismo el devenir del hombre, al contrario ve como las condiciones de libertad y dicha posibles son más tangibles, la dificultad se hace presente cuando el mismo hombre ha construido una estructura enorme de deseos, inalcanzables para la mayoría, enterrando bajo esta estructura las necesidades primarias de cada hombre. En Marcuse hay una prioridad ética por el rescate de lo que nos hace ser propiamente humanos, pero para ello hay que reducir de manera consciente la represión excedente ante la cual nos vemos sometidos pero a su vez hay que acabar con la ilusión de pretender que la libertad y la autodeterminación está en la cosificación de la misma vida:

La autodeterminación, la autonomía del individuo, se afirma a sí misma en el derecho de usar su automóvil, de manejar sus aparatos mecánicos, de adquirir una pistola, de comunicar a públicos masivos su opinión, sin que importe cuán ignorante, cuán agresiva pueda ser. (Marcuse, Un Ensayo sobre la Liberación , 1969a, pág. 20) 


\section{c) La ética ambiental}

Terminada la segunda guerra mundial los interrogantes en torno a la estabilidad del mundo hicieron presencia más activa pues ya no sólo era la lucha por el poder sino que a su vez las alarmas se encendían en diversos aspectos de las libertades humanas; factores como raza, sexualidad y medio ambiente, entre otras, pondrían en el centro de la misma Sociedad Industrial Avanzada la discusión que ya no era exclusiva de la lucha de clases. El movimiento ecologista ahondo en lo que ya Marcuse había planteado como una lucha entre el instinto de vida y el instinto de muerte, el instinto de vida se manifestaría como la lucha por la naturaleza (Eros) y el instinto de muerte es la misma civilización.

El movimiento ecologista se revela en última instancia como un movimiento de liberación político y psicológico. Es político porque se enfrenta al poder concertado del gran capital, cuyos intereses vitales este movimiento amenaza. Es psicológico, porque (y esto es un punto más importante) la pacificación de la naturaleza externa, la protección del medio ambiente de vida, también puede pacificar la naturaleza dentro de los hombres y las mujeres. Un ambientalismo éxito será, dentro de los individuos, la energía destructiva subordinada a la energía erótica. (Marcuse, 1992, pág. 36)

Una vez liberada la fuerza del instinto de vida la negatividad propendería por el equilibrio en la lucha del Principio de Realidad y el Principio de Placer pero para que dicho equilibrio sea exitoso debe introducirse en la conciencia del hombre la posibilidad de un cambio radical que enfrente al instinto de muerte pues parece que:

"No resulta ya suficiente acabar con los hombres vivos: es necesario también impedirles la existencia a los que todavía no nacieron, quemando y envenenando la tierra, defoliando los bosques, haciendo saltar los diques" (Marcuse, 1975, pág. 80).

Cuando nos preguntamos por las necesidades vitales del hombre generamos un cuestionamiento hacia aquellos factores esenciales que garantizarían el desarrollo natural del hombre, a saber: alimentarse, vivienda, sexualidad libre, ocio, etc., empero, con el Principio de Realidad reinante el hombre olvida lo fundamental y/o natural, la represión es tal que de manera casi que voluntaria el desplazamiento a la satisfacción de las necesidades 
impuestas y no vitales se convierte en el cauce inevitable de la civilización. Ahora el hombre vive la vida de la maquina: se programa con una tarea específica para la consecución de una finalidad productiva concreta. "La técnica provee la base misma del progreso; la racionalidad tecnológica establece el modelo mental y de conducta para la actuación productiva, $\mathrm{y}$ «el poder sobre la naturaleza» ha llegado a ser prácticamente identificado con el concepto de civilización” (Marcuse, 1983, pág. 89).

Para nadie es una novedad la afirmación que desde el nacimiento de la revolución industrial hasta nuestros días el hombre ha hecho uso excesivo de los recursos naturales, situación que tendría su agravante con el ascenso del capitalismo, ahora la burguesía no sólo sometería al trabajador, que en contra de la naturalidad del trabajo asume el trabajo enajenado, sino que se adueñaría de los recursos naturales óptimos para el desarrollo de sus industrias; en este orden de ideas el derecho natural al acceso justo de los recursos naturales por parte de cada hombre fue exclusivo a ciertos sectores privilegiados.

Míremelo desde la actualidad: la enajenación en el trabajo prevalece en las sociedades contemporáneas de tal manera que el desarrollo natural del hombre desde su trabajo se ve condicionada a la transformación material a favor de un paradigma económico que genera nuevas necesidades no vitales y que se ha adueñado de los recursos naturales para el beneficio particular, acá el problema ecológico no se plantea exclusivamente desde quienes y para que controlan los medios naturales sino que se enfocan a la lucha contra la destrucción que la civilización genera. Todo producto parte de una pureza material y natural que es transformada por el trabajo, pero dependiendo de tal o cual materia el trabajo condiciona el valor del producto sin importar la afectación general. "Tal como el trabajo es "creador de valores" en el plano formal, la naturaleza lo es en el plano material. No obstante (...), la separación entre sustancia natural y trabajo no puede ser de ninguna manera absoluta" (Schmidt, 1977, pág. 74).

En este orden de ideas la relación trabajo - valor y naturaleza - materia determina el costo del producto excluyendo de esta ecuación la defensa ambiental, un ejemplo de ello se hace presente en la producción bélica, terminada la segunda guerra mundial el riesgo nuclear y de una catástrofe ambiental se hizo más presente que nunca, y sin embargo la industria bélica continuaba desarrollándose desde diferentes epicentros, dificultades nucleares como 
Chernobyl-Ucrania en 1986 y reciente mente la de Fukushima- Japón en 2011, entre otras, evidenciaban tal riesgo; riesgo que no conduciría al cese de estas industrias pues el sustento de la civilización ha estado garantizado por la destrucción, por ello, el instinto de vida se hace creciente exigiendo la protección de lo más profundamente natural.

La jerarquización de las necesidades priorizan la destrucción, el avance del instinto de muerte se refleja en

...el aumento constante del presupuesto militar a costa del bienestar social, la proliferación de las instalaciones nucleares, el envenenamiento general y contaminación de nuestro entorno de vida, la subordinación flagrante de los derechos humanos a los requisitos de la estrategia global, y la amenaza de guerra en caso de un desafío a esta estrategia. Esta destrucción institucionalizada es a la vez abierta y legítima. Proporciona el contexto en el que la reproducción individual de destrucción se lleva a cabo (Marcuse, 1992, pág. 30).

El mundo desde el ocaso de la segunda guerra mundial hasta nuestros días ha venido generando un sin número de disidentes cuyas demandas exigen el fin de la destrucción que la misma súper -represión ha patrocinado la búsqueda por la liberación de la naturaleza es una ofensiva ética por parte de Eros a la Civilización. "Bajo las condiciones de la sociedad industrial avanzada, la satisfacción siempre está ligada a la destrucción. La dominación de la naturaleza está ligada a la violación de la naturaleza. La búsqueda de nuevas fuentes de energía está ligada al envenenamiento del medio ambiente vida” (Marcuse, 1992, pág. 33). 


\section{CAPÍTULO IV}

\section{LA ÉTICA DE HERBERT MARCUSE EN COLOMBIA}




\section{Introducción}

Ante la mirada superficial del colombiano común el pensamiento dentro del territorio no ha gozado de gran relevancia, al punto que gran parte de los pensadores de nuestro territorio han pasado inadvertidos en el ámbito público refugiándose sus análisis exclusivamente en los espacios privados de la academia donde inclusive su presencia es muchas veces eclipsada por el pensamiento jerárquico de occidente.

Pese al desconocimiento de gran parte de los pensadores nacionales ellos han existido y lo han hecho de manera activa dentro del mundo académico y en gran parte de los casos se ha logrado poner en diálogo las posturas extranjeras con la realidad nacional, empero, habría que afirmarlo, como ocurre en el resto de América latina también la apología ha sido constante en el pensamiento de muchos intelectuales al punto que no pareciese que están proponiendo sino simplemente son eco de la hegemonía occidental.

En este apartado intentaremos analizar los aportes que podrían generarse al poner de manifiesto los alcances de una la ética de Marcuse a lo propiamente colombiano, en este sentido, tomaremos como referentes aquellos autores que han pensado a Marcuse desde Colombia y que a lo largo del texto se irán haciendo presentes, situación que de antemano limita notoriamente el trabajo al ser pocos los pensadores quienes han elaborado análisis profundos de la obra de Marcuse, sin embargo acudiremos en algunas excepciones a pensadores cuyo referente no es nuestro pensador.

Naturalmente nos asalta la pregunta por el sentido de pensar a Marcuse para el contexto colombiano y la justificación está en que Colombia pese a tener procesos históricos diferenciados de los propiamente occidentales y latinoamericanos, la denuncia que plantea Marcuse en cuanto la ausencia de la libertad en las Sociedades Industriales Avanzadas a través de la represión excedente que de ellas emana son fenómenos palpables en el caso colombiano; en Colombia la enajenación del trabajo, lo fundamental que se vuelven los medios de comunicación para acentuar dicha represión, la ausencia de una mirada al otro y al entorno, la primacía de lo tecnológico sobre lo natural, etc., en otras palabras la figura 
del hombre unidimensional y la sociedad unidimensional hace presencia en el contexto nacional, con ello ya podríamos afirmar categóricamente que la obra de Marcuse sí merece una revisión detallada a la luz de la realidad colombiana, empero, es importante aclarar que acá no pretendemos imponer pensamientos sino simplemente utilizar las herramientas filosóficas posibles que nos permitan entender nuestra realidad e inclusive superarlas. Asimismo es pertinente manifestar que en la obra de Marcuse hay escasas aproximaciones a la realidad latinoamericana, en su obra difícilmente podamos encontrar la figura del negro, del indio, del mestizo, razón por la cual urge pensarnos éticamente en tanto que la represión occidental entra a abarcar cada vez con mayor fortaleza cada espacio de la tierra, sin importar razas, culturas, sociedades, principios, etc.

\section{II. la ética de Herbert Marcuse en Colombia}

¿Se ha tomado en serio a Marcuse? Se preguntaría el profesor Rubén Jaramillo Vélez en el encabezado de un artículo que se publicara el 5 de agosto de 1979 a razón de la muerte de Herbert Marcuse a los escasos siete días de su deceso, dicho artículo sería publicado en el Magazín Dominical El Espectador donde expone de manera muy somera pero inquietante para el lector que no ha tenido proximidad a Marcuse los rasgos más característicos de su pensamiento, más allá de brindarnos un análisis detallado de las diferentes vertientes del pensamiento de Marcuse nos invita a su lectura. Hemos tomado como referencia la pregunta acá planteada por Rubén Jaramillo Vélez para ahondar en la realidad Colombiana y a partir de este cuestionamiento desglosar alternativas éticas que dialoguen con el pensamiento de Marcuse.

Si nos preguntamos a la ligera por si se ha tomado en serio a Marcuse y limitamos el cuestionamiento a la historia del pensamiento colombiano probablemente nuestra respuesta más inmediata sería que no, siendo aquí quizás esta la intensión de Rubén Jaramillo Vélez la de poner ante los ojos del hombre común la figura de Herbert Marcuse, si bien en el ámbito académico hablar de Marcuse no es del todo ajeno tendríamos que revisar quienes lo han tomado realmente enserio más allá de vacuos acercamientos. Ahora bien, tomar en serio a Marcuse tiene ciertos niveles de rigurosidad a los cuales difícilmente se llega en la 
medida que el cuestionamiento planteado por Rubén Jaramillo Vélez exige preguntarnos no sólo si nos hemos tomado enserio a Marcuse, sino que intrínsecamente surge la pregunta por si nos hemos tomado enserio a Hegel, a Freud o a Marx, para a partir de allí poder tomarnos enserio al propio Marcuse.

Históricamente dentro del pensamiento colombiano suele caerse en la tentación de generar fanatismos en torno a determinadas corrientes filosóficas sin comprender que la tarea de la filosofía Latinoamericana y por ende Colombiana es la de estudiar el pensamiento occidental con la cautela y prudencia suficiente que nos evite ser segados por lo deslumbrante que pareciesen ser los europeísmos o norte-americanismos, pero tampoco sería razonable entrar en el radicalismo autóctono de negar herramientas fundamentales de comprensión de realidades comunes. En este sentido, tomarse enserio a Marcuse no es desde la idea clerical de imponer un catecismo que nos lleve a la salvación sino determinar con sigilo filosófico los alcances de su pensamiento ante el contexto, en este ejercicio naturalmente encontraremos caducidad de parte de su pensamiento y limitaciones que la propia realidad nacional condiciona.

Hemos afirmado que la ética Marcuseana apunta en dos direcciones específicas: a la libertad y a la dicha humana posible; si la premisa humana es alcanzar dichas posibilidades examinemos como se ha presentado dicha situación en el contexto nacional, para ello y como lo hemos anunciado indirectamente nos valdremos de las reflexiones del profesor Rubén Jaramillo Vélez y por otro lado del profesor Damián Pachón Soto principalmente en su libro la civilización unidimensional- Actualidad del pensamiento de Herbert Marcuse, al ser quienes han realizado desde nuestro sentir las aproximaciones más serias a la obra de Herbert Marcuse, sin desconocer los aportes que de manera menos rigurosa en cuanto a tomar a Marcuse como punto de partida han realizado Danilo Cruz Vélez y Darío Botero Uribe entre otros.

El caso colombiano pese a tener rasgos notoriamente comunes con la historia general de Latinoamericana como: mestizaje producto de la conquista, sometimiento a las poblaciones nativas, introducción de la esclavitud proveniente de África, independencia dentro de las 
dos primeras décadas del siglo XIX, la división ideológica en las nacientes naciones entre los ideales ilustrados de la Revolución Francesa y la conservación de la tradición ibérica, imposición y posterior adopción de la fe cristiana como única religión posible, asunción de los criollos al poder estatal, introducción del capitalismo, la llegada de una industrialización tardía frente a los procesos desarrollados casi un siglo antes en Inglaterra, sometimiento a la clase obrera a principios del siglo XX, llegada del marxismo, fomento de movimientos guerrilleros durante la segunda mitad del siglo XX etc., estos entre muchos otros aspectos marcaran la generalidad de Latinoamérica, empero, en la particularidad colombiana estos fenómenos fueron tomando matices propios e inclusive propiciando realidades independientes a las externas.

Si bien una revisión juiciosa de toda la historia de Colombia nos daría luces importantes de lo que es la realidad actual esto nos demandaría esfuerzos que probablemente nos desvíen de nuestro horizonte fundamental que es comprender la ética de la obra de Marcuse como propuesta dialógica frente a la cotidianidad nacional, sin embargo, que grave error sería negar la historia como esencia de la realidad, por lo tanto nuestro interés se centrará en el siglo XX, más concretamente en el impacto de la Sociedad Industrial Avanzada en Colombia y la represión excedente que de ella emana condicionando naturalmente las posibilidades éticas de cada individuo, es decir los alcances posibles de la libertad y dicha.

\section{La Sociedad Industrial Avanzada en Colombia}

Para principios del siglo XX Colombia aún mantenía una efímera industrialización mientras que la industria inglesa ya llevaba un siglo de desarrollo, pero de igual forma se mostraría como la panacea del progreso que de manera generalizada iba a llegar a un territorio desamparado por la máquina. No es sino hasta la década de 1920, lo que los historiadores denominan la danza de los millones, cuando la mirada de la maquinaria capitalista pondría sus ojos sobre aquellos países vulnerables del subcontinente americano, la variedad de materias primas, productos agrícolas y nuevos servicios que hasta este punto eran casi desconocidos en el territorio serían el objetivo de la industria inglesa y norteamericana principalmente. 
La novedad de la industria iba conectada con el imaginario creciente de mejoras en las condiciones de vida de la población más desfavorecida lo cual contribuyó inevitablemente a la migración interna de lo rural a lo urbano, sin embargo, no tomaría mucho tiempo para que la verdad oculta en la figura del progreso saliera y en consecuencia inexorable las protestas llegarían.

La segunda mitad de la década de los veinte estaría caracterizada por la tensión entre la maquinaria capitalista y la naciente clase obrera. La conveniente ausencia de políticas laborales con las que contaba el país permitía los excesos de las multinacionales sobre el proletariado que sin importar su vínculo con aquellas industrias fuese contratación directa o indirecta de igual forma recibían el sometimiento por parte de sus empleadores al punto que prestaciones sociales, jornada laboral, salarios dignos, etc., eran anhelos insatisfechos.

La teoría marxista a la cual se anexa Marcuse en algunos aspectos entra en sincronía con este último cuando sus reflexiones se dirigen al cuestionamiento del trabajo enajenado, la ausencia de libertad y la imposibilidad del goce, aspectos a los que se ven impedidos de acceder los hombres comunes, hasta este punto estos tres factores se hacían evidentes hasta ahora en Colombia durante la década de 1920, no con ello podemos afirmar ingenuamente que en periodos pasados de nuestra historia la dicha para nuestros hombres fuese la constante, acá lo que se manifiesta es una nueva tipología de sometimiento, el sometimiento de la industria al hombre que ya para mediados del siglo XIX esta realidad había generado escaramuzas de revolución en Europa apenas llegaba a Colombia, por tanto los tiempos históricos no coinciden, mientras el capitalismo se establecía en Europa a mediados del siglo XIX y en consecuencia su antítesis el marxismo daba a luz una de las principales corrientes filosóficas de la historia reciente en Colombia esto estaba lejano a la realidad.

...el Movimiento socialista nació de la revuelta de los hombres aplastados por las maquinas de la primera revolución industrial. Y como en la segunda mitad del siglo pasado (XIX) nuestras sociedades no habían sufrido los efectos de esa revolución, es claro que no se podía 
hablar de un socialismo que tuviera por detrás una clase trabajadora multitudinaria, organizada y consciente (Molina, 1983, pág. 33)

Habíamos esquematizado en apartados anteriores la génesis de la Sociedad Industrial Avanzada, sin embargo, esta caracterización que realizamos la analizamos desde un contexto occidental indiferenciado explicando cómo desde el nacimiento del hombre contemporáneo se fue tejiendo lo que con Marcuse llamamos la Sociedad Industrial Avanzada que tiene su expansión en la segunda mitad del siglo XX hasta nuestros días, pero en el ámbito particular, para este el caso colombiano, si bien es una realidad condicionada por lo que llamamos occidente internamente la situación ha tenido características especificas impregnadas de incertidumbres que sólo propicia la ausencia de autonomía nacional. Mientras occidente veía como de manera exitosa en Rusia ascendían al poder los bolcheviques y Estados Unidos de Norte América se convertía en la principal potencia mundial en los llamados países subdesarrollados las tensiones se vivían de manera particular.

El sometimiento del obrero colombiano en multinacionales como la Tropical Oil Company en el caso de la explotación petrolera principalmente en Barrancabermeja y la United Fruit Company en Ciénaga Magdalena quienes extraían banano propiciaron naturalmente protestas, por más débiles y serviles que parecíamos, como lo había planteado Hegel en la filosofía de la historia cuando hacía referencia a el nuevo mundo, los limites soportables habían desaparecido, más allá del involucramiento de posturas socialistas las protestas no fueron fruto de la ideología sino de la represión, represión que posteriormente se traduciría en la voz del socialismo, en este sentido, es un absurdo pretender que el éxito de la revolución bolchevique fomentara las protestas en el territorio cuando la misma realidad desencadeno dichas protestas; en un territorio acostumbrado a la derecha cualquier manifestación contra ella debe ser rotulada sin importar desde donde venga, y no es suficiente con señalarla, una vez evidenciada hay que eliminarla; bajo esta lógica se desarrolla uno de los más penosos episodios de la historia nacional del siglo $\mathrm{XX}$, que hasta la pluma de Gabriel García Márquez no fue ajena: la masacre de las bananeras de diciembre 5-6 de 1928. 
En paralelo a los inicios de la Sociedad Industrial en Colombia sus detractores iban creciendo, como es natural y ya lo hemos referido, los ideales socialistas y/o comunistas iban avanzando dentro de la sociedad colombiana, sin embargo hay que ser enfáticos en este punto, pues la ideología creciente era apenas una superficial lectura de Marx, "Es bien probable que en la mayoría de los casos, del propio Marx sólo conocieran el Manifiesto del partido Comunista, limitándose su apropiación del materialismo histórico a obras de divulgación" (Jaramillo Vélez, 1998, pág. 139) que a manera de manuales o catecismos circularon en Colombia a lo largo del siglo XX.

El cambio de bando político al cual se vio sometida la nación en 1930 colocaría casi sin alternativa de elección al partido liberal; militantes del Partido Revolucionario Socialista se anexarían al programa liberal principalmente a lo que se denomino la revolución en marcha de Alfonso López Pumarejo que generaría reformas constitucionales en el año de 1936, por ello afirmamos que resultaba bastante tibia la presencia socialista en las contiendas electorales y esto seguiría dándose hasta el término de la primera mitad del siglo XX.

El 17 de julio de 1930, en una manifestación en la que se produjeron choques con algunos liberales que protestaron contra los ataques al recientemente elegido Olaya Herrera, se hizo pública la fundación del Partido Comunista, un acontecimiento que en opinión de uno de sus más acerbos críticos- el socialista Antonio García - significó el que un movimiento que había tenido la capacidad de movilizar a los sectores más representativos de la clase trabajadora, de los campesinos, y a la élite intelectual de la pequeña burguesía, había sucumbido a la tentación de convertirse en una "iglesia revolucionaria minúscula y autosuficiente". (Jaramillo Vélez, 1998, pág. 154)

El marxismo en Colombia ha sido tibio y ambiguo, por una parte el conocimiento serio del pensamiento de Marx, como pensamiento y no como doctrina, ha sido escasamente estudiado, esto significaría verlo a la luz de nuestra realidad y no desde la caverna de occidente donde se pretende que occidente es un todo homogéneo cuyo remedio es genérico a cualquier patología que dentro de él se manifieste; y por otro lado quienes han abanderado el marxismo en Colombia como estrategia de cambio han favorecido la lucha 
armada por encima de la teoría crítica y reflexiva que fomenta el mismo marxismo, sumado a ello la historia de Colombia del siglo XX hasta nuestros días ha sido una traducción de la Doctrina Truman potenciada a la lucha contra el socialismo y contra cualquier oposición a la ultra derecha nacional, acá lo que vivimos no es un conflicto entre el capitalismo y el socialismo, sino una lucha del capitalismo frente a todos los marginados: clases sociales, razas, ideologías, libertades sexuales, medio ambiente, estudiantes, etc., en este sentido el marxismo sería seriamente abordado hasta la segunda mitad del siglo XX, a través de la divulgación de materiales académicos en revistas especializadas. "Tal vez constituyan estos aportes de la revista Estrategia - principalmente de los Arrubla, Estanislao Zuleta y Jorge Orlando Melo- el primer capítulo de u "marxismo académico". (Jaramillo Vélez, 1998, pág. 177).

Acá nos resulta casi imposible dejar de lado a Estanislao Zuleta, si bien la teoría crítica no es el centro de indagación del pensador colombiano está en estrecha relación con lo que algunos pensadores de la escuela de Frankfurt desarrollaron en sus obras, para el caso que nos compete va en la misma dirección analítica a la cual Herbert Marcuse se enfoca; Zuleta a través de un cuidadoso ensayo logra poner en diálogo lo que se había asumido como opuesto: la teoría marxista y el psicoanálisis.

Normalmente se asume que el individuo va por una parte y la sociedad por otra donde el primero es consecuencia del segundo, lo que en realidad se ve en la teoría marxista y que tanto en Zuleta como en Marcuse lo analizan suficientemente es que la sociedad es un conjunto de individualidades que han sido permeadas en el inconsciente desde una estructura social dominante que el mismo hombre ha creado. Cuando Marx pronunciaba la lucha de clases entre la burguesía y el proletariado estaba poniendo en cuestión las limitaciones a las que se ven enfrentados individualmente los hombres desposeídos cuya realidad social no es una deidad incuestionable que simplemente se debe tolerar; cuando Marx cuestiona la sociedad y considera la posibilidad de una mejor dentro del comunismo inmersamente está lanzando una postura ética donde individualmente cada hombre tiene la posibilidad de acceder al trabajo no enajenado, la satisfacción de sus necesidades vitales y al disfrute de una vida autónomamente gobernada, sin embargo esta situación no es 
palpable ni en Colombia ni en occidente, lo que realmente ocurre es que estos tres aspectos fundamentales de la vida humana "se separan y se disocian hasta fijarse en individuos y en clases diferentes". (Zuleta, 1985, pág. 206)

El camino hacia la Sociedad Industrial Avanzada en Colombia va a andar en paralelo con el desarrollo del marxismo y más aun durante el siglo XX, ya posesionada la industria extranjera la burguesía se fue reafirmando en el dominio económico y el individuo simplemente era un espectador de la situación, aquellos más osados o más obligados empezarían a estructurar movimientos revolucionarios y más aun cuando procesos internacionales servirían influyentes en el desarrollo del marxismo en Colombia "Tres acontecimientos internacionales incidirían en la evolución del marxismo en Colombia. En primer lugar, el XX congreso del partido comunista de la URSS (...), la dirigencia del Partido Comunista chino" (Jaramillo Vélez, 1998, pág. 163) y la revolución cubana.

La aclimatación del materialismo en nuestra sociedad no es de ningún modo casual. Más lentamente que en otras sociedades americanas, la nuestra ingresó fatalmente al estadio de la modernidad. La sociedad de masas plantea una gama de problemas que no se pueden eludir y no se pueden reconocer sin el concurso del materialismo histórico. Pero de un materialismo abierto, crítico, que de ningún modo se ha anquilosado para devenir, como dice Adorno, en una "religión secular" de Estado. Sin aferrarse a ninguna doctrina, fuertemente arraigado en el imperativo materialista de trabajar para la liberación y la redención de la vida humillada, el pensamiento crítico mantiene - frente a los afectos de una cultura gastada: el rencor, el resentimiento y el recelo - la fe en la dignidad del pensamiento reflexivo, reitera como válida la consigna de la Ilustración: Sapere Aude! Atrévete a usar de tu propio entendimiento. (Jaramillo Vélez, 1998, pág. 190)

Una evidencia del establecimiento de la Sociedad Industrial Avanzada en el país se hace notaria en la medida en que las históricas fuerzas revolucionarias del proletariado van perdiendo su poder y van siendo absorbidas por el sistema que a base de artimañas van estableciendo conductas que dentro de un masoquismo social van flagelando inconscientemente la propia libertad intercambiándola por estereotipos de dicha provisoria, ahora si sumamos en Colombia no sólo la represión excedente natural de la Sociedad 
Industrial Avanzada sino también la violencia el resultado es mayor garantía para la burguesía nacional quien se va afianzando mientras el pueblo en un estado de pasividad y de aceptación de lo dado ve como los adversarios político-ideológicos y la complicidad del poder con el narcotráfico y bandas criminales garantizan la manipulación y el control:

Por lo que se refiere a la manipulación y control sistemáticos de psique en la sociedad industrial avanzada hay que preguntarse: manipulación y control ¿para qué, y por quien? Además de todas las manipulaciones particulares en interés de ciertos grupos de negocios, medidas políticas o camarillas, el objetivo general propuesto es reconciliar al individuo con el tipo de existencia que su sociedad le impone. (Marcuse H. , 1981, pág. 106)

En esta reconciliación no hay espacio para la protesta, para el inconformismo, sino simplemente para la constante represión: "La civilización es represión en sí misma, la represión implica una carencia de libertad que impide la felicidad del hombre, así las cosas, la civilización industrial avanzada no es más que la represión llevada a uno de sus más altos niveles" (Pachón Soto, 2008, pág. 60).

La revisión de Marcuse en nuestras sociedades se justifica en la medida que el individuo ha perdido su libertad a cambio de un mundo cosificado que el principio de Realidad ha arrojado sobre él como la panacea de felicidad y en acompañando al pensamiento de nuestro autor tendremos que estar del lado de la libertad, empero, no con esto estaríamos afirmando que Marcuse es la llave maestra que abre cualquier cerrojo social hacia la libertad, por tanto la pregunta que nos sale al camino es hasta donde Marcuse puede ser útil en la comprensión ética de nuestras sociedades.

Como ya hemos afirmado no es el mismo génesis de la Sociedad Industrial Avanzada del mundo puramente occidental, por puro nos referimos a dominante y precursor de este tipo de sociedad, a la que marca la historia de Colombia desde la décadas de los años veinte del siglo XX hasta nuestros días, si bien hay hallazgos que nos indican la existencia de una sociedad industrial en Colombia como lo son la represión excedente, la alienación del trabajo, la perdida de contradicción en la sociedad entre dominados y dominantes, etc., en el país la Sociedad Industrial Avanzada ha unido vínculos fuertes con sociedades 
industriales de mayor dominio, en este sentido, la represión excedente podríamos decir que no sólo rompe con culturas ancestrales y tradiciones especificas para incorporarlas a una macro cultura de represión sino que la represión excedente tiene doble impacto: uno desde el propiamente extranjero donde se asume el otro no como el dominante sino como el estereotipo a seguir y otra represión propiamente interna que en el país tiene un historial importante casi desde los albores de la independencia que en híbridos político religiosos ha sometido la sociedad colombiana.

La sociedad industrial avanzada en Colombia surge como un inexacto reflejo de lo que Marcuse llama sociedad opulenta, es decir, que acá genéticamente heredamos la esencia de este tipo de sociedad pero que con el ingreso a la nación se particularizó como lo diría Fals Borda:

Mal haríamos, al estudiar nuestra sociedad actual en Colombia, por ejemplo, en pensar que la expansión del capitalismo dominante hubiera ido desplazando de manera definitiva las formas anteriores de producción, que en nuestro caso son las que provienen del señorío colonial, del latifundismo, del pequeño propietario campesino (modo de producción mercantil simple) y aun más atrás, de las formas de comunitarismo primitivo en sus dos modalidades de primitivismo puro y del tributario. Si nos vamos al terreno, en regiones como la Costa atlántica (...) se verá que allí persisten y sobreviven estos modos, llamados antiguos, pre - o no - capitalistas, a pesar de la expansión capitalista que los afecta (Fals Borda, 1983, pág. 18)

Colombia se caracteriza por tener dentro de ella sociedades convenientemente temerosas, acá el temor se constituye en un factor extra para la represión excedente, no sólo es la represión simbólica que se vale de estrategias para entrar directamente en el aparato psíquico del individuo sino que a su vez la violencia goza de tal naturalidad que la ausencia de ella inquieta, tal es la naturalización de la violencia que hasta los mismos medios de comunicación parcializados con poco tacto dividen la percepción de quienes habitan el territorio, en una sociedad unidimensional no hay nada más útil que tener la garantía del control sobre los medios de comunicación; la circulación de un diario informativo al servicio del Estado, los dos principales canales televisivos pertenecen a los dos más grandes 
grupos económicos del país, la educación se mercantiliza acorde a las necesidades del sistema, la iglesia pese a sus constantes escándalos continua imponiendo irónicamente posturas morales, el indio es incivilizado, el negro socialmente inferior y en el marco de estas particularidades habita el hombre común, el hombre unidimensional que sigue las exigencias imperceptibles de los mass media.

Pero resulta particularmente peligroso en la coyuntura contemporánea, por la injerencia de los medios masivos de comunicación y en general de la tecnología, que esa premodernidad y esa minoría de edad -en términos psicológicos podrían considerarse también como "debilidad del yo" - puedan ser manipuladas en un sentido antidemocrático, en general, a través de y en dirección a la banalidad: banalidad y democracia deberían ser incompatibles, lo que no sucede en Colombia (Jaramillo Vélez, 2004, pág. 144)

Seguimos creyendo ingenuamente dentro de la Sociedad Industrial Avanzada que este es el mejor de los mundos posibles porque es el mundo de los objetos, ellos determinan quienes somos, nuestra libertad se realiza en la medida que podamos aproximamos a la tenencia de los objetos y nuestra dicha no es sensible sino racionalista, es decir, lo que aparece ante nosotros como espejismo fruto de un progreso se desvanece en el anhelo, pero es bajo la idea del anhelo que persiste el individuo dentro de la sociedad unidimensional pues ha puesto su fe, sus metas, su vida en la asunción a una burguesía que simplemente le arroja objetos que alimentan tal esperanza. A pesar de vivir un mundo de frustraciones el consuelo está en la imagen, por ejemplo el auge de los realitys shows sostiene su éxito en el juego con el inconsciente que pretende verse reflejado en el otro, el principio de placer reprimido ve su satisfacción cuando a través de un monitor el individuo ve su vida en el otro con la seguridad que el otro hace lo que para él está prohibido, en este sentido el control esta en el voyerismo exacerbado, mientras nuestras mentes se recrean desde la comodidad de un sillón implícitamente nuestros deseos empiezan a desear lo que desde el principio de realidad es deseable. Para el caso colombiano la represión nunca ha sido extraña, el éxito de la imposición religiosa hasta nuestros días continúa dando frutos al punto que por un lado es arrojada una conciencia moral religiosa y por el otro la permisibilidad de lo anti ético. "El Dios de Moisés, sin nombre y sin imagen, es, en su concepción misma, una poderosa represión de todo lo sensual que se adhiere a la vida imaginaria y al lenguaje, y proviene de 
cierta forma de liquidación de la organización matriarcal de la sociedad”. (Zuleta, 1985, pág. 221). En nuestro territorio el espíritu religioso ha sido escasamente modificado respecto de los últimos dos siglos, ese Dios que todo lo ve y que todo lo puede refuerza el principio de realidad establecido en la medida que el individuo no sólo limita su vida pública ante las normas impuestas, sino que su vida privada mantiene el control de un Dios omnipresente, en Colombia ética y moral son dimensiones claramente diferenciables e indisociables, la libertad sexual, el feminismo, las protestas obreras, las manifestaciones estudiantiles, las causas indígenas y afro, la defensa del medio ambiente, entre otras se muestran en los medios como un absurdo y un sin sentido, empero, la violación de derechos fundamentales, la escasa protección de la infancia, la corrupción, la apología al crimen, el inoperante sistema judicial, etc., resultan aceptables.

Lo mejor que pudo hacer el sistema para controlar a los hombres es meternos en los hogares un nuevo miembro de la familia a quien escuchar pacientemente y aceptar sus lineamientos; el ingreso de la televisión en Colombia durante el gobierno del general Gustavo Rojas Pinilla el 13 de junio de 1954 abrió las puertas a una nueva etapa de la Sociedad Industrial, fue el paso firme de ir de una Sociedad Industria a la Sociedad Industrial Avanzada, desde este momento el ideal del progreso se justificaba en la tenencia del aparato audiovisual, desde él un horizonte de libertad se veía cada vez más lejano pero qué importaba si ahora el escaso tiempo libre del trabajador podía dedicarlo a este nuevo miembro familiar, no era relevante que años después de inaugurada la televisión en Colombia se estableciera el frente nacional o que los movimientos revolucionarios de campesinos, de indígenas herederos de Quintín Lame, de estudiantes, y hasta de curas salieran a flote, porque ahora la realidad era la que se veía por televisión y otra la que se vivía en los campos y en las ciudades remotas del Estado nacional, creímos tocar la libertad a manos llenas:

Marcuse opina, al contrario, que lo que resulto del creciente progreso de la sociedad industrial fue más bien la creciente esclavización del hombre de una producción sin límites y de un consumo sin sentido y, respecto al trabajador específicamente, el cambio de una dependencia personal por otra dependencia más tiránica, por la dependencia del aparato de producción y de los aparatos de manipulación y control (Cruz Vélez, 2014, pág. 304) 
Si bien Colombia como país en vía de desarrollo marca notorias diferencias frente a la Sociedad Industrial Avanzada como la norte americana o sociedad opulenta como era categorizada por Marcuse, podríamos decir que a nuestro modo la sociedad Industrial avanzada es palpable en el país, en cuanto a las diferencias podemos citar las siguientes valiéndonos del mismo Marcuse:

1) La mayoría de los "productores inmediatos" viven en condiciones de miseria y de intolerable explotación, y la abolición de dichas condiciones implica la abolición del sistema social vigente:

2) Las reducidas clases dominantes son evidentemente incapaces de promover bajo su propia dirección, el desarrollo de las fuerzas productivas; por consiguiente, la explotación de los nativos es protegida y perpetuada por potencias extranjeras, y la revolución social coincide con la liberación nacional.

3) Hay un maduro liderazgo combatiente que promueve activamente la organización de la población sometida y el desarrollo de su conciencia (Marcuse H. , 1969, pág. 47)

Esta caracterización que realiza Marcuse y que hemos usado como referencia para entender nuestro proceso histórico resulta profundamente cierta para la Colombia de la década de los sesentas y setentas, exceptuando el ítem tercero las demás caracterizaciones son palpables para nuestra historia actual, por su parte la madurez de un liderazgo combatiente ha perdido su fuerza histórica en profundas ambigüedades de relación de la violencia con la reivindicación social. Es evidente que en toda Sociedad Industrial Avanzada aquellas bases pre-revolucionarias se desvanecen en el poderío del sistema, en este punto el proletariado debilitado pierde su esencia fundamental de cara al cambio:

Es decir, que para hacer la nueva revolución no se puede contar con el proletariado, pues este ha sido ya asimilado por el establishment; pero tampoco se puede contar con ninguno de los partidos o grupos de oposición existentes, porque ellos también pertenecen al "sistema", que los tolera para asegurar su predominio, al hacerlos inofensivos, comprometiéndolos en un juego político de tira y afloja controlado por él; y, en general, no se puede contar con nadie ni nada que esté dentro del establishment jugando su juego. (Cruz Vélez, 2014, pág. 307) 
No podemos estar plenamente de acuerdo con la lectura que hace el profesor Cruz Vélez de la obra de Marcuse cuando señala que ya no podemos contar con el proletariado, el proletariado sigue siendo la fuerza por excelencia de una revolución marxista, la tarea no está en descartarlos sino en concientizarlos de su papel histórico, resultaría contradictorio poner un fatalismo en la obra de Marcuse cuando está llena de un optimismo, donde las puertas para liberar al hombre se abren a nuevas posibilidades, con lo que si podemos estar de acuerdo es que el papel de la revolución es un papel ético donde deben aflorar las voces de los excluidos que no son exclusivamente el proletariado, el propósito ético de la obra de Marcuse es liberar al hombre desde su misma autoconciencia.

\section{El trabajo en las sociedades industriales colombianas}

El trabajo que creó y aumentó la base material de la civilización fue principalmente trabajo con esfuerzo, enajenado, doloroso y miserable - y todavía lo es-. (Marcuse H. , 1984, pág. 89)

Como vimos anteriormente la llegada de la industria extranjera al país genero nuevas divisiones del trabajo, el paso de un trabajador campesino rural a un obrero industrial significaría la ruptura de dinámicas laborales extrañas que bajo la promesa del progreso generaron rápidamente adeptos y otros tantos por obligación económica, pues su situación miserable en el campo pedía nuevas alternativas de subsistencia, a lo largo del siglo XX hasta nuestros días en Colombia se ha vislumbrado una dialéctica entre el campo y ciudad, puesta en términos de barbarie o civilización, asumimos que el progreso provenía de la industria extranjera y los estereotipos que de allí se han importado, el trabajo con esfuerzo, enajenado, doloroso y miserable como no lo dice Marcuse: aumento la base material de la civilización y para nuestro caso generó una amalgama entre la burocracia nacional y el 
imperialismo extranjero. Empero pensar en una sociedad sin represión excedente no es un proyecto utópico desde Marcuse sino una posibilidad latente.

Por ello, lo que planteará en El final de la utopía, de una u otra manera debe algo de la primera etapa de su pensamiento: que a consecuencia del proceso tecnológico y la convergencia de los múltiples factores que configuran la circunstancia de plenitud de la modernidad, se producirá inclusive un cambio biológico; que surgirán nuevas necesidades y que la urgencia y la exigencia de libertad, ahogada por el conformismo del hombre unidimensional, el ciudadano corriente de la sociedad del capitalismo tardío, producirá esa transformación (Jaramillo Vélez, 2013, pág. 184)

Entonces, si bien el panorama actual de represión ha alcanzado niveles antes insospechados el fatalismo y aceptación de lo dado no es una condición que se perciba en la obra de Marcuse, por el contrario, las posibilidades de revolución aun palpitan tímidamente dentro de las mismas Sociedades Industriales Avanzadas, ya no es sólo el trabajador aislado quien exija una justicia social, sino diferentes frentes sociales cuya represión excedente los ha obligado a la existencia desde barreras simbólicas a la libertad. "Plantea Marcuse que el trabajo implica un apropiarse del mundo exterior” (Jaramillo Vélez, 2013, pág. 194); en este apropiarse significa Ser desde su mayor autenticidad y esto en país como Colombia abre un panorama de plural de posibilidades: no sólo el obrero, sino junto con él está el indio, el campesino, el negro, la mujer, el estudiante, etc.

Ya lo que aparece ante mí no exige la categorización kantiana de dado fenómeno, el fenómeno en la Sociedad Industrial Avanzada existe por su determinado valor de cambio, en este sentido el hombre se aproxima al objeto no desde su esencialidad sino desde su superficial valor mercantil; asimismo el hombre al adueñarse de un objeto ya enajenado y que a su vez lo condiciona entra en mayores niveles de enajenación pues no sólo su trabajo lo enajena, sino que el producto de éste sirve a la adquisición de productos enajenantes que condicionan la realidad humana, en este orden de ideas el hombre entra en la unidimensionalidad que Marcuse nos ha alarmado desde los primeros años de la década de los sesenta, entonces, la propiedad privada es herramienta y sinónimo de la represión excedente. 'En el Estado de la propiedad privada un objeto se vuelve se vuelve 'propiedad' 
al poder ser 'utilizado' y éste utilizar consiste tanto en un consumo inmediato del objeto como en su “capitalizabilidad”” (Jaramillo Vélez, 2013, pág. 195).

El producto del trabajo en la sociedad industrial avanzada tiene su uso en la adquisición de productos enajenantes, en la era de los artefactos, ellos jerarquizan la existencia, y la propiedad privada manifiesta un seudo-Ser, un Ser animado por la acumulación de capital, el hombre ha sacrificado toda libertad individual por la apariencia de una libertad social, por la satisfacción de placeres no vitales; aquí en Colombia donde las brechas sociales son palpables con tal claridad que el rico y el pobre no tienen puntos de encuentro como muchas veces ocurre por ejemplo en la sociedad opulenta, donde el pobre siente acceder a la burguesía por la tenencia de determinado artefacto, en Colombia hay regiones donde ni siquiera el impacto de la tecnología ha logrado enajenar al hombre pues su pobreza es tal que el Estado difícil mente llega allí, regiones aisladas del pacifico, algunos sectores del Caribe, la amazonia entre otros desconocen el impacto real de la sociedad industrial avanzada sobre el hombre citadino que unidimensionalmente ha crecido, por ello el exotismo cultural es tan presente en nuestro territorio, pues los hombres de la sociedad unidimensional se maravillan y sorprenden de aquellas culturas y regiones no permeadas por la sociedad industrial avanzada, empero, allí el proceso mercantil entra en acción, pues la extrañeza cultural y ambiental entran en el mercado.

Marcuse con su idea de revolución radical que comprende también esa dimensión - es que el hombre ha de ser cada vez más rico y que el comunismo, considerado como el resultado final de la historia y la superación de la propiedad privada, deberá inaugurar esa riqueza, esa posibilidad de experimentar todas las dimensiones del Ser, no restringidas, como hasta ahora, no limitadas por la propiedad privada. (Jaramillo Vélez, 2013, pág. 194) 


\section{BIBLIOGRAFÍA}




\section{Bibliografía}

Botero, U. D. (2007). Vitalismo Cósmico. BOGOTÁ - COLOMBIA: Corteza de Roble.

Cruz Vélez, D. (2014). De Hegel a Marcuse. Obras Completas II. Bogotá - Colombia: Universidad de los Andes - Universidad de Caldas - Universidad Nacional de Colombia.

Fals Borda, O. (1983). Marx y el Tercer Mundo. En: El marxismo en Colombia. Bogotá - Colombia: Universidad Nacional.

Freud, S. (1993). Los Textos Fundamentales del Psicoanálisis . Barcelona-España: ALTAYA.

Gadamer, H.-G. (2006). Estética y Hermenéutica. Madrid-España: TECNOS/ALIANZA.

Hegel, F. (1963). Lecciones sobre la Filosofía de la Historia Universal. En: La filosofía en sus textos . Barcelona - España: Labor.

Hobsbawm, E. (2012). La era de la revolución (1789-1848) / La era del capiltal (1848-1875) / La era del imperio (1875-1914). Barcelona - España: Planeta.

Jaramillo Vélez, R. (1998). Colombia: la modernidad postergada. Bogotá - Colombia: Gerardo Rivas Moreno.

Jaramillo Vélez, R. (2013). El concepto de trabajo en Marcuse. Aquelarre. Revista del Centro Cultural Universitario , 169-200.

Jaramillo Vélez, R. (1991). Presentación de la Teoría Crítica de la Sociedad. Bogotá - Colombia: Fundación Editorial Argumentos.

Jaramillo Vélez, R. (2004). Problemática actual de la democracia : historia de los derechos humanos, sobre el orígen de la esfera de lo público, vocación por el saber y la emancipación, sobre autoritarismo, docencia y el estado precario de la modernidad en Colombia... Bogotá - Colombia: Ediciones Jurídicas Gustavo Ibañez.

Locke, J. (2010). Segundo tratado sobre el Gobierno Civil. Un ensayo acerca del verdadero origen, alcance y fin del Gobierno Civil. Madrid - España: Tecnos.

Mansilla, H. (1970). Introducción a la teoría crítica de la sociedad. Barcelona - España: Seix Barral.

Marcuse, H. (1976). A la Búsqueda del Sentido. Salamanca - España: Ediciones Sígueme.

Marcuse, H. (1983). Calas en Nuestro Tiempo. Barcelona-España: ICARIA.

Marcuse, H. (1967). Cultura y Sociedad. Buenos Aires - Argentina : SUR.

Marcuse, H. (1992). Ecology and the Critique of the Modern Society. Capitalims, Nature, Socialism. Vol $3,29-38$. 
Marcuse, H. (1975). Ecología y Revolución. En H. M. Otros, La Lucha por la Extensión del Mundo de la Belleza, de la no-violencia, de la calma, es una lucha política (págs. 77-85). Buenos AiresArgentina : EDICIONES NUEVA VISIÓN.

Marcuse, H. (1986). El final de la utopía. Bogotá-Colombia: Planeta-Agostini.

Marcuse, H. (1985). El Hombre Unidimensional. Ensayo sobre la ideología de la sociedad industrial avanzada. Barcelona - España: Planeta Agostini.

Marcuse, H. (1971). El Materialismo Soviético . Madrid-España: ALIANZA.

Marcuse, H. (1972). Ensayos sobre Política y Cultura. Barcelona-España: ARIEL.

Marcuse, H. (2011). Entre Hermenéutica y teoría crítica. Artículos de 1929-1931. Barcelona España: Herder.

Marcuse, H. (1983). Eros y Civilización . Madrid-España: SARPE S.A.

Marcuse, H. (1970). Ética de la Revolución . Madrid-España: TAURUS.

Marcuse, H. (2001). Guerra, Tecnología y Fascismo. Textos Inéditos. Medellín - Colombia : UNIVERSIDAD DE ANTIOQUIA - UNESP.

Marcuse, H. (1981). La agresividad en la sociedad industrial avanzada. Madrid - España: Alianza Editorial.

Marcuse, H. (1975). la lucha por la extensión del mundo de la belleza, de la no-violencia, de la calma, es una lucha política. En M. H. Otros, Ecología y Revolución (págs. 77-85). Buenos AiresArgentina : EDICIONES NUEVA VISIÓN.

Marcuse, H. (1969). La Sociedad Industrial y el Maxismo . Buenos Aires-Argentina: Quintaria.

Marcuse, H. (1994). Razón y Revolución. Hegel y el surgimiento de la teoría social. Barcelona España: Altaya.

Marcuse, H. (1969a). Un Ensayo sobre la Liberación . México D.F: JOAQUÍN MORTIZ.

Marcuse, P. y. (1976). A la búsqueda del sentido. Salamanca - España: Ediciones Sígueme.

Marx, C. (1968). La ideología alemana. Montevideo-Uruguay: Ediciones Pueblos Unidos.

Marx, K. (1950-53). El Capital. Crítica de la Economía Política. México D.F: EDICIONES FUENTE CULTURAL.

Marx, K. (1968). La Ideología Alemana. Montevideo - Uruguay: Ediciones Pueblos Unidos. 
Molina, G. (1983). El Pensamiento Marxista en América Latina. En: El marxismo en Colombia. Bogotá-Colombia: Universidad Nacional .

Montesquieu. (1963). El Espíritu de las Leyes. En: la filosofía en sus textos. Tomo II. Barcelona España: Labor.

Nietzsche, F. (1994). Aurora. Madrid-España: M.E. EDITORES.

Ortega y Gasset, J. (1988). La Rebelión de las Masas. Madrid-España: ALIANZA EDITORIAL.

Pachón Soto, D. (2008). La civilización unidimensional. Actualidad del pensamiento de Herbert Marcuse. Bogotá - Colombia: Ediciones Desde Abajo .

Palmier, J. (1969). En Torno a Marcuse. Madrid - España: Crónica de un Siglo.

Platón. (1966). La República. Barcelona-España: OBRAS MAESTRAS.

Proudhon, P. J. (2001). ¿Qué es la propiedad? Barcelona-España: Folio.

Rousseau, J. J. (1963). Del Contrato social, o principios de derecho político. En: La filosofía en sus textos. Tomo II. Barcelona-España: Labor.

Schmidt, A. (1977). El concepto de Naturaleza en Marx. España: Siglo Veintiuno editores.

Voltaire. (1963). Tratado de metafísica. En: La filosofía en sus textos tomo II. Barcelona - España: Labor.

Wiggershaus, R. (2011). La escuela de Fráncfort. Argentina: Fondo de Cultura Económica.

Zuleta, E. (1985). Marxismo y psicoanálisis. En: La filosofía en Colombia -Siglo XX. Pág:203-228. Compilación Rubén Sierra Mejía. Bogotá - Colombia: Procultura S.A. 


\section{CONCLUSIONES}




\section{CONCLUSIONES}

Los individuos introyectan los valores y objetivos que se incorporan en las instituciones sociales, en la división social del trabajo, en la estructura de poder establecido, y así sucesivamente. Y por el contrario, las instituciones y las políticas sociales reflejan (tanto en la afirmación y la negación) las necesidades de los individuos socializados, que de esta manera se convierten en sus propias necesidades (Marcuse, 1992, pág. 32).

Hemos querido dejar un apartado para poder, a manera de balance, determinar los alcances de este trabajo y los horizontes que de él se puedan desprender.

Tendríamos que afirmar categóricamente que la obra de Marcuse posee un profundo sentido ético, como debe ser en cualquier obra de filosofía que pretenda materializarse en una realidad concreta alejada de la especulación idealista, pues cual sería el sentido de una filosofía sin cambio. Más allá de reflexiones vacuas, en Marcuse podemos vislumbrar un notable optimismo hacia la liberación, alejado de toda resignación conceptual que acepta un final de la historia, en nuestro autor lo que sí es posible es un final de la utopía.

Este final de la utopía al que hace referencia Marcuse es un re-pensar desde la más real posibilidad al acceso a la liberación del hombre, por ello la liberación de los instintos vitales es y será una lucha frente el principio de realidad establecido, empero, pensar en un hombre ético no significa la negación de la represión o fin del Principio de Realidad, acá de lo que se trata es de liberar al hombre de la represión excedente. Tarea no menor.

Acordamos que la ética tiene que estar en constante armonía entre el Principio de Realidad y el Principio de Placer enmarcado en un presente, sabemos que el dominio de un principio 
sobre otro nos puede conducir a la pérdida parcial o total de la libertad o en el otro extremo establecernos en estados primitivos.

Si bien los recursos técnicos que tenemos nos podrían conducir a libertad y dicha para todos, es decir, hoy en día tenemos las capacidades jamás alcanzadas para la democratización de la libertad y dicha posible la pregunta es cómo hacerlo. La respuesta habita en la misma dialéctica. ¿Por qué dirigirnos a la dialéctica?

Las tensiones existentes en la Sociedad Industrial Avanzada pueden encontrar un equilibrio que garantice la libertad y dicha posible del hombre, su sociedad y su entorno "consiste el equilibrio entre la voluntad y el deseo de vivir, y de su voluntad y el deseo de destruir la vida" (Marcuse, 1992, pág. 31).

Hasta acá hemos realizado una somera caracterización de la teoría ética en la propuesta crítica de Herbert Marcuse, ahora el horizonte goza de gran amplitud de posibilidades de indagación donde las propuestas nos acerquen a un hombre libre y dichoso, la misma Sociedad Industrial Avanzada ha generado su propia negación, es decir, que en el seno del mismo instinto de destrucción de la civilización se encuentra su destrucción.

Al igual que ha ocurrido con todos los pensadores dialécticos su estudio debe realizarse a la luz de la pertinencia del contexto, estos pensadores dialécticos han dejado para la historia un legado filosófico inconcluso que sólo el devenir histórico puede completar, la misma dialéctica exige su constante renovación, por eso la obra de Herbert Marcuse debe analizarse desde su caducidad y desde su actualidad.

Lastimosamente para el caso colombiano las referencias a Marcuse son escasas y las pocas existentes se han dedicado a pensar a Marcuse desde su generalidad, situación que no es una deficiencia pues la virtud de ellos está en poner a Marcuse como un pensador actual en el contexto nacional sugiriendo la tarea por ellos iniciada de ahondar en su pensamiento desde el marco de nuestra realidad. Es decir pensar a Marcuse desde Colombia es mirar la represión excedente no sólo desde lo planteado por nuestro pensador, sino que debemos ir al indio, a nuestras selvas, a nuestra sociedad industrial, a nuestras guerras, mafias, 
corrupción, hombres, etc., en este sentido este trabajo pretende abrir las puertas de nuestra comprensión desde Marcuse.

Jairo A. González Moreno 